\title{
DEMOCRACY AND DYSFUNCTION: AN EXCHANGE
}

\author{
SANFORD LEVINSON* \\ JACK M. BALKIN ${ }^{* *}$
}

September 29, 2015

Dear Jack,

It is obviously no longer controversial that the American political system, especially at the national level, is seriously dysfunctional. Consider, for example, what are nearly the opening words-after noting that the United States Capitol is currently enfolded by scaffolding for repair of the physical building-of the distinguished Columbia political scientist and historian Ira Katznelson's recent contribution to a Boston Review forum on "Anxieties of Democracy." ${ }^{1}$ Even if "[r]estoration is underway, its conclusion in sight," repair of the institutions inside the Capitol seems a long way off, if it is even possible. ${ }^{2}$ Katznelson continues:

The House and Senate are presently shackled. Paralyzed by party divisions, influenced excessively by moneyed interests, and perverted by the disappearance of civic virtue, representative institutions appear unable to identify and address our most consequential public problems, including the politics of redistribution, racial equity, immigration, and the proper balance between liberty and national security. Like the dome, American democracy badly needs reconstruction. ${ }^{3}$

* Professor Sanford Levinson, who holds the W. St. John Garwood and W. St. John Garwood, Jr. Centennial Chair in Law, joined the University of Texas Law School in 1980. Professor Levinson is also, in both fall 2015 and 2016, a visiting Professor of Law at Harvard Law School. He was elected to the American Academy of Arts and Sciences in 2001 and received the Lifetime Achievement Award from the Law and Courts Section of the American Political Science Association in 2010. Among his books is Framed: America's 51 Constitutions and the Crisis of Governance (2012). This Article is a revised version of the presentation Professor Levinson gave during the Indiana Law Review Symposium held on November 6, 2015 entitled Partisan Conflict, Political Structure, and Culture.

** Professor Jack M. Balkin is Knight Professor of Constitutional Law and the First Amendment at Yale Law School and the founder and director of Yale's Information Society Project, an interdisciplinary center that studies law and new information technologies, as well as the director of the Knight Law and Media Program and the Abrams Institute for Free Expression at Yale. He is a member of the American Academy of Arts and Sciences and founded and edits the group blog Balkinization. This Article is a revised version of the presentation Professor Balkin gave during the Indiana Law Review Symposium held on November 6, 2015 entitled Partisan Conflict, Political Structure, and Culture.

1. Ira Katznelson, Anxieties of Democracy, Bos. Rev. (Sept. 8, 2015), http://bostonreview. net/forum/ira-katznelson-anxieties-democracy [https://perma.cc/8EY2-7TXU].

2. Id.

3. Id. (At the time of this publication, the restoration of the U.S. Capitol Dome has 
Depending on one's place along the political spectrum, one might see different examples of the particular failings of Congress - and, for that matter, of the presidency and judiciary. Those on the right presumably are not so upset that the only interest most of Congress has in "the politics of redistribution" is to take from the less well-off and give to the wealthy via tax cuts and continuing subsidies disproportionately received by the well-off. As I write this opening missive, on September 28, 2015, Real Clear Politics, aggregating a number of recent polls, indicates that while approximately fifteen percent of the public "approves" of Congress, seventy-five percent does not. ${ }^{4}$ The "direction of country" data indicates that only very slightly more than a quarter of polled Americans believe the country is heading in the right direction, while sixty-three percent (including yours truly) believes we continue on a downward slope.

Katznelson offers a fairly familiar litany of examples of what "shackle[s]" our present system, including polarization, the obscene role played by money in the overall electoral process, and, interestingly enough, "the disappearance of civic virtue." With regard to the last of these, one can well wonder exactly when a sufficient supply of such virtue in fact graced our political order. One can scarcely understand the Publian ${ }^{7}$ argument for adoption of the Constitution as resting on a robust confidence in the virtue of the populace at large. Were that the case, one might have expected something other than the exclusive reliance on representatives and the absolute shackling of the public at large with regard to any direct participation in governance. ${ }^{8}$ There is a reason, after all, that Publius takes great pride in, and indeed capitalizes, what he regards as one of the strongest features of the new constitutional order: "THE TOTAL EXCLUSION OF THE PEOPLE, IN THEIR COLLECTIVE CAPACITY," from any share in actual governance. ${ }^{9}$ Decisions are to be made only by those deemed, with whatever empirical accuracy, the "representatives" of the people. ${ }^{10}$ But, of course, an important aspect of the initial Publian schema is that these representatives

concluded and the scaffolding removed; however, the metaphor employed by Katznelson, alas, still remains all too apt.)

4. Congressional Job Approval, REAL CLEAR Pol., http://www.realclearpolitics.com/epolls/ other/congressional_job_approval-903.html [https://perma.cc/W3LD-X6P2] (last visited Nov. 8, 2016).

5. $I d$.

6. Katznelson, supra note 1.

7. See SAnford Levinson, An Argument Open to All: Reading the Federalist in the 21st CENTURy (2015) (noting that Publius was the pen name chosen by Alexander Hamilton, John Jay, and James Madison when they collaborated on writing the 85 essays comprising The Federalist).

8. The Federalist No. 63 (James Madison).

9. The Federalist No. 63, at 373 (James Madison) (Isaac Kramnick ed., 1987); see also LEVINSON, supra note 7, at 240-41.

10. Id. 
would in fact be markedly "better" than their constituents. ${ }^{11}$ They not only would be more sophisticated about the ways of the world, but also, and more importantly, more disposed to tame the inevitable and ineradicable urges of selfinterest, delineated most sharply in The Federalist No. 10, and to be guided instead by the demands of the public good. ${ }^{12}$ That vision of "enlightened" representation seems far in the past; the only serious debates are whether the Publian vision ever made much sense and when it collapsed, perhaps with the emergence of the first party system around $1796,{ }^{13}$ the rise of mass political parties during the Jacksonian Era, ${ }^{14}$ or the rise of the modern mass-and then social-media state in the twentieth and twenty-first centuries. ${ }^{15}$ (You certainly know far more about this last than I do, and, of course, much of your previous work also emphasized the crucial role of social movements in understanding the actualities of American constitutional development. ${ }^{16}$ )

As you no doubt can predict, given our many conversations (and joint seminars) on the general subject of the state of the American politics, what upsets me about Katznelson's analysis - and, for that matter, the responses offered by a variety of talented academics and social activists - is that none of them, save perhaps for Helene Landemore,$^{17}$ comes close to addressing the possibility that among the cause of our present discontents is the institutional order created in 1787 and left remarkably unchanged since then. ${ }^{18}$ It is especially telling that this failure of imagination is found in a symposium that is quite obviously dominated by persons of leftish sensibilities. ${ }^{19}$ They are, after all, fully aware of the deficiencies of our present political system and believe that reform-generally of

11. The Federalist No. 10, at 128 (James Madison) (Isaac Kramnick ed., 1987) ("[A]nd the suffrages of the people being more free, will be more likely to centre in men who possess the most attractive merit and the most diffusive and established characters.").

12. Id. at 125 .

13. See Nancy L. Rosenblum, On the Side of Angels: An Appreciate of Parties And PARTISANSHIP 89-94 (2010) (outlining how the Federalists hoped "to abolish factions and unite all the parties for the general welfare").

14. See Jacksonian Democracy, HistORY, http://www.history.com/topics/jacksoniandemocracy [perma.cc/WA27-9ECV] (last visited Nov. 8, 2016).

15. See Rosenblum, supra note 13, at 341 (summarizing the effect that modern focus on media by "would-be party builders" has inhibited the possibility of a sustainable new political party that could rival the current two-party system).

16. See generally Jack M. Balkin, The Last Days of Disco: Why the American Political System is Dysfunctional, 94 B.U. L. REV. 1159 (2014).

17. Helene Landemore, Responding to Anxieties of Democracy, Bos. Rev. (Sept. 8, 2015), http://bostonreview.net/forum/anxieties-democracy/h\%C3\%A $91 \% \mathrm{C} 3 \% \mathrm{~A} 8$ ne-landemore-landemoreresponse-anxieties-democracy [https://perma.cc/N3N9-ZAA6].

18. Id.

19. See Katznelson, supra note 1 (referencing published responses from Larry Kramer, David M. Kennedy, Mark Schmitt, Rick Perlstein, Mohammad Fadel, Michael C. Dawson, Helene Landemore, Michael Gecan, Martin O’Neill, Nadia Urbinati, Melissa S. Williams, Alex Gourevitch, and Richard Trumka). 
the kind that I presume both of us would favor-is necessary. ${ }^{20}$ And there was a time, of course, when leftish critics were also at the same time critics of the Constitution itself. ${ }^{21}$ Perhaps they accepted, rightly or wrongly, the Beardean understanding ${ }^{22}$ that it was intended to-and did-operate to serve particular economic interests, none of them identified with the working class (or, even more certainly, that subset of the working class called slaves). Or perhaps they were angry at the totally unjustifiable power given small, usually rural, states in the Senate. It is surely no coincidence, to adopt a classic formulation of the left, that Socialist Representative Victor Berger, ${ }^{23}$ representing Milwaukee early in the twentieth century, believed that popular election of senators, achieved via the Seventeenth Amendment in 1913, was far inferior to the out-and-out abolition of that egregious institution. Again, one might agree or disagree with him, just as one might or might not agree with, say, Teddy Roosevelt, who campaigned in 1912 on the platform that the American electorate should be given the right to overturn offensive judicial decisions by popular referendum. ${ }^{24}$ The point is that the agenda of political reformers once included "constitutional reform" in a sense far different from supplicating judges for attractive decisions. ${ }^{25}$ But that has been lost, save, interestingly enough, for certain members of the Tea Party who would like, for example, to repeal the Seventeenth Amendment ${ }^{26}$ (not to mention the Sixteenth Amendment licensing the federal income tax). ${ }^{27}$ That spirit seems

20. $I d$.

21. See generally Robert W. Gordon, The Struggle over the Past, 44 CLEV. ST. L. REV. 123 (1996) (detailing examples of the evolving legal theories of "classic" and "progressive" liberalism in contrast to the "New Right" and paradigmatic back-and-forth use of the Constitution to further one side's cause or blunt the other's).

22. See Charles Austin Beard, 1 Economic Interpretation of the Constitution of THE UNITED STATES 325 (1913) ("In the ratification, it became manifest that the line of cleavage for and against the Constitution was between substantial personalty interests on the one hand and the small farming and debtor interests on the other. The Constitution was not created by 'the whole people' as the jurists have said; neither was it created by 'the states' as Southern nullifiers long contended; but it was the work of a consolidated group whose interests knew no state boundaries and were truly national in their scope.").

23. Wants Senate Abolished: Berger of the House May Be Disciplined for Criticism in Resolution, N.Y. TIMES, Apr. 28, 1911, at 8.

24. President Theodore Roosevelt, Candidate for President in 1912, A Charter of Democracy Speech before the Ohio Constitutional Convention (Feb. 21, 1912) (transcript available through the Theodore Roosevelt Digital Library at Dickinson State University), http://www. theodorerooseveltcenter.org/Research/Digital-Library/Record.aspx ?libID $=0285145$ [https://perma.cc/7VJH-TZBN].

25. Id.

26. Evan McMorris-Santoro, Tea Party-Backed Repeal of the 17th Amendment Gets Republicans into Trouble, TALKIng Points Memo (May 14, 2010, 8:13 PM), http:// talkingpointsmemo.com/dc/tea-party-backed-repeal-of-the-17th-amendment-gets-republicans-intotrouble [https://perma.cc/5DQR-ZHA5].

27. Brian Beutler, 5 Constitutional Amendments that Constitution-Loving Tea Partiers 
completely absent in the contemporary left, including that portion of the left represented (or, some would say, over-represented) in the legal academy. Thus, as you know, my principal caveat with regard to the book you co-edited with our friend Reva Siegel for the American Constitution Society (ACS) (which I am glad to support)-The Constitution in $2020^{28}$ - was devoted exclusively to judiciallymanaged reform and had no discussion at all of the possibility that members of the ACS should actually ask if we need something that judges cannot in fact provide, which is fundamental institutional change. ${ }^{29}$

Let me stop now. I trust I have said enough to initiate this epistolary exchange that also serves as our contribution to the symposium in Indianapolis on "Partisan Conflict, Political Structure, and Culture." ${ }^{30}$ There is much to be said about American political culture; as Mark $\mathrm{Graber}^{31}$ has sometimes suggested, we may need new kinds of citizens rather than a new Constitution. ${ }^{32}$ Similarly, partisan conflict of the kind analyzed by, say, Norman Ornstein and Thomas Mann, ${ }^{33}$ is surely worth a great deal of emphasis. But I hope that "political structure" does not get lost in the conversation. Are we well served by the set of structures created in 1787, and could we do better? I believe that the answer to the first question is clearly no, and I am agnostic about the possibility of doing better. But we will never know unless we begin a full-scale conversation about what institutional transformation might actually involve.

I look forward to reading your reply.

Sandy

October 12, 2015

Dear Sandy,

It might be useful to organize the issues raised by your initial comments into three sets of questions.

First, is the United States presently in a period of political dysfunction? What

Would Change, Talking Points Memo (Oct. 28, 2010, 12:41 PM), http://talkingpointsmemo. $\mathrm{com} / \mathrm{dc} / 5$-constitutional-amendments-that-constitution-loving-tea-partiers-would-change [https://perma.cc/KY68-E7LD].

28. See generally Jack M. Balkin \& Reva Siegel, The Constitution in 2020 (2009).

29. Id.

30. See supra note *.

31. See, e.g., Mark A. Graber, The Countermajoritarian Difficulty: From Courts to Congress to Constitutional Order, 4 ANN. REV. L. Soc. ScI. 361, 366-67 (2008).

32. Id.

33. See, e.g., Thomas Mann \& Norman Ornstein, It's Even Worse Than It Looks (2012) (stating Congress has become stalled due to both parties moving to left and right sides, rejecting bi-partisanship, and becoming passionately adverse). 
features or aspects of the political system evidence this dysfunction or are themselves dysfunctional?

Second, is there a better way to describe our current set of problems than political dysfunction?

Third, are our present problems caused by hard-wired features of the American Constitution, or are they caused by other features of the constitutional system? Is a constitutional amendment or a new constitutional convention the appropriate remedy for these problems, or would other kinds of remedies prove more effective or appropriate?

\section{IS THE PROBLEM DySFUNCTION?}

You begin by asserting that no one seriously doubts that the United States is currently in a period of political dysfunction. But I think the question is far more difficult. That is because the term "dysfunction" is quite ambiguous.

If "dysfunction" means that politicians are unable to perform the ordinary tasks of governance, it is by no means clear that the national government is dysfunctional. It all depends on whose perspective you are taking. The Debt Ceiling Crisis of 2011 caused enormous anxiety. ${ }^{34}$ Yet it led to the Budget Control Act of $2011,{ }^{35}$ which, if you are a Republican, was an enormous policy success because it slowed the growth of federal spending. Again, if you are a Republican, you might well rejoice in the fact that the percentage of the workforce employed by federal, state, and local governments has significantly decreased during Barack Obama's presidency, ${ }^{36}$ although, as a Republican, you

34. Jack M. Balkin, The Not-So-Happy Anniversary of the Debt-Ceiling Crisis, THE ATLANTIC (Jul 31, 2012), http://www.theatlantic.com/politics/archive/2012/07/the-not-so-happyanniversary-of-the-debt-ceiling-crisis/260458/ [perma.cc/WGV6-4TA2].

35. Budget Control Act of 2011, Pub. L. No. 112-25, 125 Stat. 240 (codified as amended in scattered titles of the U.S.C.).

36. See, e.g., Drew Desilver, Job Shifts Under Obama: Fewer Government Workers, More Caregivers, Servers and Temps, PEW RES. CTR. (Jan. 14, 2015), http://www.pewresearch.org/facttank/2015/01/14/job-shifts-under-obama-fewer-government-workers-more-caregivers-servers-andtemps/ [https://perma.cc/5T7J-2XMG] ("Private payrolls have added 7 million jobs over Obama's presidency, while government payrolls (federal, state and local) have contracted by a combined 634,000 jobs."); Ben Walsh, Here's An Obama-Era Legacy No One Wants to Talk About: Government Jobs Have Fallen, HufFington Post (Aug. 5, 2016), http://www. huffingtonpost.com/entry/obama-austerity-legacy-jobs_us_57a499ece4b03ba68012032b [https://perma.cc/4695-42HF] ("The decline has come at the state and local level. It coincides with state and local budgets around the country being slashed. Federal public sector jobs have been basically flat for the past eight years - if you strip out the temporary bump for the hiring of shortterm workers once a decade for the census."); Joshn Zumbrun, The Federal Government Now Employs the Fewest People Since 1966, Wall St. J. (Nov. 7, 2015), http://blogs.wsj.com/ economics/2014/11/07/the-federal-government-now-employs-the-fewest-people-since-1966/ [https://perma.cc/P4LS-YL9N] ("As a share of the total workforce, the federal government's share of civilian employment is the lowest since World War II.”). 
might be loath to give Obama credit for this.

If by dysfunction you mean that the President and Congress do not seem to agree on anything these days, the upcoming 2016 election would seem to provide an easy cure. Simply elect a Republican to the White House, end the legislative filibuster, and the problem is solved. Then the national government would be like many state governments with one-party rule. These governments are able to pass a great deal of legislation. Many of these reforms are ill-advised, but that does not mean that these state governments are dysfunctional. It means only that democratic governments sometimes produce very unwise policies.

Now if the thought of a Republican Congress headed by President Trump, Rubio, or Jeb Bush disturbs you far more than the status quo, it is not clear to me that what you really are worried about is dysfunction. That is because you are presumably delighted that Obama (and forty-six Democrats and independents in the Senate ${ }^{37}$ ) stand ready to prevent Republicans from dismantling not only Obamacare, but large chunks of the New Deal and the modern welfare state. Rather, your real objection is to policies that you dislike. Your problem is that a substantial percentage of the American public disagrees with you about public policy and does not want the same things that you want. Your problem is not dysfunction - it is control (or blocking) by your political opponents.

Perhaps the problem boils down to the concern that the U.S. government is dysfunctional because (pending the results of the 2016 election) it is easier to push policies in a direction Republicans like, and it is harder to push them in a direction that many Democrats like. That may not in fact be true, but even if it were true, one would then have to couple this claim with the (contestable) assertion that the Democrats, for all their faults, are closer to the real or genuine interests of the public and of democracy generally, regardless of what the opinion polls say. But I am not sure that the best way to describe this state of affairs is political dysfunction.

Perhaps by "dysfunction" we mean polarized parties and irresponsible politicians. One might point to bitter ideological division between the two major political parties, and to the remarkably irresponsible economic views held by one of them (I will not say which one!) which block a rational response to our current economic problems. Yet the United States weathered the greatest challenge of the past decade-The Great Recession-far better than most other Western democracies, including those with parliamentary systems that do not have the multiple veto points that the U.S. Constitution has. ${ }^{38}$ For all of the inanity of our

37. Party Division in the Senate, 1789-Present, U.S. SenATE, http://www.senate.gov/ history/partydiv.htm [https://perma.cc/CKY3-GSA6] (last visited Nov. 11, 2016).

38. See, e.g., Marilyn Geewax, U.S. Economic Recovery Looks Good Compared With Sluggish Europe, Asia, NPR (June 17, 2016), http://www.npr.org/sections/thetwo-way/2016/06/17/ 482328208/u-s-economic-recovery-looks-good-compared-with-sluggish-europe-asia [https://perma.cc/UUS3-X8HR] ("the OECD says that compared with our chief competitors, the United States is leading [the Euro Area and Japan in its recovery from the Great Recession] - by miles."); Maria A. Arias \& Yi Wen, Recovery from the Great Recession Has Varied Around the World, FED. RES. BANK OF ST. LOUIS (Oct. 2015), https://www.stlouisfed.org/ /media/ 
political classes, and the many veto points in our system, we must be doing something right.

Or we might identify "dysfunction" with lack of public trust in government. One might point to the public's loss of trust in the federal government and the general sense (judging from recent public opinion polls ${ }^{39}$ ) that the country is moving in the wrong direction. But as Steve Griffin points out in his recent book on constitutional dysfunction, the public has been losing trust in government for many decades, going back to the $1960 \mathrm{~s}^{40}$ This decline began long before the period that one might assert is the present period of dysfunction. ${ }^{41}$ Perhaps even more embarrassing, much of the decline begins during a period of great achievement for democracy and equality in the United States. ${ }^{42}$ It is precisely when government becomes more equal, fair, and open that Americans begin to lose trust in their government. ${ }^{43}$ Pessimism about the country's general direction is not the same thing as lack of trust in government. Such pessimism about the country's general direction tends to fluctuate with the business cycle and with the state of the economy, and may also vary depending on party affiliation. ${ }^{44}$

Finally, I should note that my own view, outlined in my essay The Last Days of Disco ${ }^{45}$ is that what we are calling dysfunction is actually transition between constitutional or political regimes. The Republican regime that has dominated American politics since 1980 is nearing its end. Although the Republicans still dominate Congress and state legislatures, ${ }^{46}$ the two parties are increasingly evenly matched, and demographic shifts, as well as a continuing civil war within the Republican Party, appear to be sapping the Republicans' long dominance. ${ }^{47}$ Eventually a new regime will emerge, and when it does, people will stop complaining how dysfunctional our system is, just as they stopped complaining about dysfunction during Roosevelt's and Reagan's presidencies. ${ }^{48}$

Calling our system "dysfunctional," then, may not clarify matters because it runs together several phenomena: (1) polarization; (2) venality; (3) idiocy; (4)

Publications/Regional\%20Economist/2015/October/recession.pdf[https://perma.cc/B2TW-N9PQ] (finding the GDP growth of the United States was higher than Western Europe).

39. Trust in Government: 1958-2015, PEw Res. CTR. (Nov. 23, 2015), http://www.peoplepress.org/2015/11/23/1-trust-in-government-1958-2015/ [https://perma.cc/4RM6-7WYX] ("The public's trust in the federal government continues to be at historically low levels. Only $19 \%$ of Americans today say they can trust the government in Washington to do what is right 'just about always' (3\%) or 'most of the time' (16\%).").

40. Stephen M. Griffin, Broken Trust: Dysfunctional Government And CONSTITUTIONAL REFORM 76 (2015).

41. Id.

42. Id. at 80 .

43. Id. at $90-91$.

44. Id. at 10 .

45. Balkin, supra note 16 , at 1160-61.

46. Id. at 1169.

47. Id. at 1170 .

48. Id. at 1172 . 
ineffectiveness (given a particular political perspective or ideology); (5) lack of representativeness; and (6) transition between constitutional regimes. This brings me to the second question. Is there a better way to describe our current set of problems? I believe there is.

\section{The Problem Is Democracy, Not Dysfunction}

The term "dysfunction" suggests that some function of government is not working properly. ${ }^{49}$ But the term remains ambiguous until we specify what the relevant function is. Government might be dysfunctional because it does not function well as a government-for example, because it can not make decisions, because it can not appropriate and spend money, because it can not raise or support troops, or because it can not respond to crises like the Great Recession. I have suggested above that none of these are really the case. Or government might be dysfunctional because it fails at a different criterion: it does not function well as representative government.

The latter, I think, is the real issue. To be sure, our present degree of polarization and political conflict naturally causes people to confuse the question of representativeness with the question of efficacy, but the two questions are not the same. An efficacious government need not be representative and it can feature a great deal of polarization and conflict. Indeed, an efficacious government can exacerbate polarization and conflict precisely because it is efficacious in a particular way or in a particular direction. During the Obama Administration, for example, the government made significant reforms to the health care and financial systems; these reforms seem to have made polarization worse, not better. Conversely, a representative government that truly reflects the diverse opinions of Americans may not be particularly efficacious or efficient.

Moreover, if, as I believe, we are in a period of transition between regimes, we should expect a considerable amount of angst about democracy and worries that government no longer works as well as it once did. These concerns tend to happen precisely during such periods of transition..$^{50}$ Think of the period between 1928 and 1933, for example, or the period between 1978 and 1984. These worries, however, will likely resolve themselves over time as the Reagan regime breaks down and is replaced by a new regime-whether one dominated by Democrats or Republicans. ${ }^{51}$ If that is what people mean by dysfunction, it is only a temporary problem.

Nevertheless, there is a quite different concern that is wrapped up in our current anxieties. I believe that it is a real problem, one that needs a solution, and that it will not be solved simply by waiting things out. But this problem is not primarily a problem of efficacy or a problem of polarization, although it may exacerbate both phenomena.

The big problem that we face today is that our system of democratic

49. See generally GRIFFIN, supra note 40 .

50. Id. at 1160-61.

51. Id. at 1160-61, 1192-93. 
representation is broken. ${ }^{52}$ The system of representation is not broken because it fails to produce winners and losers who claim to represent us. It produces plenty of winners and losers, and politicians endlessly insist that they are working the people's will and doing the people's business. Rather, the system of representation is broken because it is seriously undemocratic and unrepublican. It is undemocratic because it is not responsive to public opinion. It is unrepublican because it is not fairly representative, allows too much selfentrenching behavior, is deeply corrupt, and is not directed at the achievement of the public good. ${ }^{53}$

To be sure, this $i s$ a kind of dysfunction. After all, one of the functions of a democratic government is to be democratic. The function of a republican government is to represent the public and serve the public good. Our current system of government is defective in both respects. But we should not confuse this kind of dysfunction with the claim that the government can't get certain things done. Thus, instead of talking generally about political dysfunction, we should focus on what is really at stake-democracy and republicanism. The question we should ask is what features of our current system are deeply and pathologically undemocratic or unrepublican.

You have been arguing about these issues for a long time, Sandy-long before the current controversies over government dysfunction. ${ }^{54}$ Indeed, even if our system of government was efficacious, I believe that you would still object that it is not sufficiently democratic. Our current political unhappiness merely gives you the opportunity to call for reforms that you would have advocated regardless of the public's current degree of satisfaction (or dissatisfaction) with their government.

Your previous work has tended to equate the question of political dysfunction with the question of how directly and rapidly our institutions respond to public opinion, ${ }^{55}$ and especially with how easy it is for the public to change directions through legislation or through initiative or referendum. ${ }^{56}$ That is why you are skeptical of the presidential veto, for example. But, as noted above, we should not run together questions of democracy and representativeness with questions of efficacy. That is because relatively undemocratic and unrepresentative systems

52. Id. at 1190.

53. The republican political tradition is quite complicated and has both desirable and undesirable elements. For a summary of its constitutional relevance today, see Jack M. Balkin, Which Republican Constitution?, 32 ConsT. Comm. 31 (2017); Jack M. Balkin, Republicanism and the Constitution of Opportunity, 94 TEx L. REV. 1427 (2016). In this discussion, I use the term "republican" to describe the admirable features of the republican tradition that emerged from its synthesis with liberalism and that were embraced by the Constitution's framers.

54. See, e.g., Sanford Levinson, Our Undemocratic Constitution: Where the Constitution Goes Wrong (And How We the People Can Correct It) (2006).

55. Sanford Levinson, The United States and Political Dysfunction: "What Are Elections for?, " 61 DRAKE L. REV. 959 (2012).

56. Sanford Levinson, How the United States Constitution Contributes to the Democratic Deficit in America, 55 DraKe L. REV. 859, 874 (2007). 
can function very effectively. In many respects the United States was undemocratic and unrepublican by today's standards throughout most of its history. Although it sometimes functioned quite badly-think only of the period leading up to the Civil War-it also often functioned quite well. (Indeed, if you think that the Jacksonian period was a period of increasing democracy, that was also the period that brought us closer to civil war.)

I agree with you that there are features of our political system that are deeply and unfairly undemocratic. The most important is our system of campaign finance, and relatedly, our system of lobbying and access to representatives. A second problem is the urgent need to reform our representational and voting systems. Even without reforming the malapportioned Senate, there is much we could do to reorganize democratic politics, make registration and voting easier, and increase participation.

These undemocratic and unrepublican features of our system do not necessarily make it dysfunctional from the standpoint of efficacy. There have been long periods of time in the United States in which wealth and capital dominated political agendas and in which either a large percentage of ordinary people were disenfranchised or their votes and voices were unfairly neglected and ignored. These periods of time include periods that most people would not consider dysfunctional, even though there was also a significant amount of party polarization.

I also do not think that reforming campaign finance and voting will necessarily make government more efficient or effective. It may or may not lead to wiser decisions. These reforms may not make polarization go away, or increase public trust. If Steve Griffin is right, then making government more accountable and transparent may actually increase public distrust. ${ }^{57} \mathrm{I}$ am not at all sure that these reforms will prevent showdowns like the confrontations we have seen in the past eight years. What they will tend to produce is not less dysfunction, but more democracy_or at least a more fairly representative government.

Perhaps equally important, even if we focus on the question of democracy as opposed to efficacy, you and I might disagree about different features of our system and their relative importance. For example, I do not find the presidential veto a particularly serious problem, while you do ${ }^{58}$ I do not think that moving up the date of Inauguration Day is all that important, while you have repeatedly pointed to it as a defect of our Constitution. ${ }^{59}$ Finally, although I agree that the Senate is drastically malapportioned, I do not think that abolishing it is a very high priority, while it is a major concern of yours. I might choose a different mix of reforms: some might be more "republican"-seeking to improve representation

57. See GRIFFIN, supra note 40, at 75-78 (connecting loss of trust in government with increase in civil rights and civil liberties, which made politics more divisive and made government malfeasance more salient).

58. See Sanford Levinson, Against the Veto, New Republic (Oct. 9, 2006), https://newrepublic.com/article/64983/against-the-veto [https://perma.cc/U6V6-YM8K].

59. See, e.g., Sanford Levinson, The "Dysfunctional Constitution" Thesis, 43 ConN.L. Rev. 987, 995 (2011). 
in different areas, preventing self-entrenchment, and rooting out political corruption. Others might be more "democratic"-facilitating mass participation and the practical ability to vote.

\section{Is THE HARD-W iRed CONSTitution the PROBlem?}

These differences in priorities bring me to the third set of questions. Are the anti-democratic (or anti-republican) features of our government primarily caused by hard-wired features of the U.S. Constitution, or by other causes? And what is the appropriate remedy for these problems?

Here it is important to make a distinction between the constitutional order and the hard-wired Constitution. ${ }^{60}$ The constitutional order is the entire set of rules, doctrines, and practices that structure political decision making in the United States. ${ }^{61}$ The hard-wired Constitution consists of those rules embedded in the document that cannot be changed except by constitutional amendment. ${ }^{62}$

Your work has tended to equate constitutional reform with altering the hardwired Constitution. ${ }^{63}$ This requires either Article $\mathrm{V}$ amendment or a new constitutional convention. ${ }^{64}$ That may be because you think that the most important problems with the Constitution come from its hard-wired features.

By contrast, I do not believe that the most serious problems with our system come from its hard-wired features. Most of the constitutional order is not hardwired. Therefore, I also do not believe that the most important reforms to our constitutional order require Article $\mathrm{V}$ Amendment or a new constitutional convention. I have no objection to either-I am not, like some of our colleagues, an amendment-phobe or a convention-phobe. It is just that I do not believe that these are the appropriate cure. We can reform some of the most important features of our constitutional system through statutory changes. For example, we can move from single member districts in the House to other forms by ordinary statute. States can change their voting, registration, and redistricting systems without a federal constitutional amendment. Even some features of the system that seem hard-wired, like the Electoral College, can be worked around through ordinary politics. For example, states can bargain around the Electoral College through an interstate compact ratified by Congress. ${ }^{65}$ To be sure, pushing for new

60. Balkin, supra note 16, at 1162-64 (distinguishing between the hard-wired Constitution and the Constitution of construction).

61. Id. at 1166.

62. Id. at 1163 .

63. See, e.g., Levinson, supra note 55, at 981 ("I have come to believe that the most important aspects of any constitution are the hard-wired structures within which politics takes place.").

64. Id. at 980-81.

65. See Akhil Reed Amar, AmericA's Unwritten Constitution: The Precedents And Principles We Live By 457-61 (2012); Vikram David Amar, Response: The Case for Reforming Presidential Elections by Subconstitutional Means: The Electoral College, the National Popular Vote Compact, and Congressional Power, 100 GEO. L.J. 237, 254-58 (2011). 
amendments or a new convention may raise public support for statutory or administrative solutions that do not require supermajority votes in the Congress and the states. So pushing for amendments may sometimes be politically advantageous to achieving strategies that do not require amendments.

Another example is the current dysfunction in the House of Representatives, in which the Speaker is repeatedly forced to engage in political brinksmanship before finally allowing essential legislation to pass with Democratic votes. The problem stems from internal rules of the Republican Caucus. The "Hastert Rule," for example, is a political convention under which the Speaker of the House refuses to allow a vote on legislation supported by a majority of the House unless a majority of his or her party's caucus also supports it. ${ }^{66}$ In addition, current House rules effectively prevent any Republican Speaker from being elected without the consent of the House's Freedom Caucus; this holds the Speaker hostage to the House's most ideologically extreme elements. ${ }^{67}$

These difficulties are not due to the hard-wired Constitution. Although Article I, Section 2, Clause 5 of the Constitution prescribes that "[t]he House of Representatives shall choose their Speaker and other Officers," specify how this is to be accomplished. There are any number of nonconstitutional reforms that would prevent the current system of dysfunction we are witnessing in the House.

Some reforms, especially in the area of campaign finance, may require changes in constitutional doctrine. Constitutional amendment is probably the least effective way to achieve them. Changing doctrine normally requires that judges change their minds or, more likely, that new presidents appoint new judges. If one amends the Constitution but leaves the same judges in place, there is the risk that the judges will neuter the changes. That is why Franklin Roosevelt decided to focus on new judicial appointments instead of Article V amendments. ${ }^{69}$

I agree with you that law professors tend to focus obsessively on the work of judges and pay less attention to questions of constitutional design. I agree that they should shift more of their attention to questions of constitutional design. It does not follow, however, that they should shift their attention to Article V

66. Balkin, supra note 16 , at 1166 .

67. Sarah Binder, This Is How the Freedom Caucus Has Taken the House Hostage, WASH. Post (Oct. 12, 2015), https://www.washingtonpost.com/news/monkey-cage/wp/2015/10/12/this-ishow-the-freedom-caucus-has-taken-the-house-hostage $/$ ?utm_term $=.13925 \mathrm{e} 2 \mathrm{c} 4833$ [https://perma.cc/CE66-4HJN] (describing how the Freedom Caucus used the vote for Speaker to control the House's political agenda).

68. U.S. Const. art. I, $\S 2$, cl. 5.

69. Franklin D. Roosevelt, Fireside Chat, The Am. Presidency Project, (Mar. 9, 1937), http://www.presidency.ucsb.edu/ws/?pid=15381 [https://perma.cc/WH25-9EPP] ("Even if an amendment were passed, and even if in the years to come it were to be ratified, its meaning would depend upon the kind of Justices who would be sitting on the Supreme Court bench.”). 
amendment, much less to a new constitutional convention. Rather, they should focus on features of the constitutional order that can be modified both at the state and federal levels by a combination of legislative, administrative, and doctrinal reforms.

Jack

October 12, 2015

Dear Jack,

As always, you raise a number of excellent questions. We may disagree less than you think, but where we do disagree may be important (especially from the perspective of those interested in the symposium of which these exchanges are a part). Indeed, in the interim between my first letter and this, the House of Representatives has been thrown into chaos by the joint phenomena of the apparent resignation by Speaker John Boehner ${ }^{70}$ and the seeming inability of the Republican caucus to agree on a successor who in fact is willing to take that thankless job. ${ }^{71}$ [Since these comments were written, the Republicans did settle on Paul Ryan to be Speaker, ${ }^{72}$ but now the punditry speculates on whether he will in fact be able to "tame" the Republican caucus ${ }^{73}$ especially given his insistence on adhering to the Hastert rule ${ }^{74}$ whereby he will refuse to bring up any legislation that does not have the support of a majority of the Caucus.] How indeed does one bring order to a group that is engaged in what increasingly appears to be full-scale political warfare at least as much with fellow Republicans as with the quite literally hated Democrats? It is difficult not to take quite literally "current events" into account in terms of the wider analysis of "Partisan Conflict, Political Structure, and Culture." Perhaps readers, knowing how the story has turned out, at least provisionally, will use that knowledge to reinforce or cast doubt on our own "real-time" analyses. But, of course, the greatest challenges

70. Jennifer Steinhauer, John Boehner, House Speaker, Will Resign from Congress, N.Y. Times (Sept. 25, 2015), http://www.nytimes.com/2015/09/26/us/john-boehner-to-resign-fromcongress.html?_r=0 [https://perma.cc/KN6W-95FH].

71. Kelsey Snell, Why Paul Ryan Doesn't Want to Be House Speaker, WASH. Post (Oct. 8, 2015), https://www.washingtonpost.com/news/powerpost/wp/2015/10/08/why-paul-ryan-doesntwant-to-be-house-speaker/ [https://perma.cc/X9YN-HF3Y].

72. Deirdre Walsh, Paul Ryan Elected House Speaker, CNN (Oct. 29, 2015), http://www.cnn.com/2015/10/29/politics/paul-ryan-house-speaker-vote/[https://perma.cc/3RSH4JEE].

73. Scott Wong, Speaker Ryan Courts Conservatives, THE Hill (Jan. 26, 2016, 6:00 AM), http://thehill.com/homenews/house/266890-ryan-seeks-to-court-conservatives [https://perma.cc/2H97-FQET].

74. Balkin, supra note 16 , at 1166. 
come when we bring to bear our techniques of analysis, whether strictly legal or drawing on insights from political science, history, or whatever on immediate events of great importance where we cannot, by definition, be confident of outcomes.

Let me address your three points in turn:

\section{I. "FUnCTIONALITY" AND "DYSFUnCTIONALITY"}

First, as to the meaning of "dysfunctionality," you are absolutely right. Perhaps, like most terms that we throw about in our political discourse-think also of such favorites as "democratic" or "republican" forms of government- "functionality" and "dysfunctionality" are what political theorists call "essentially contested concepts." 75 The importance of such concepts lies not only in the fact that smart people of good faith in many cases have disagreed for literally centuries about their meanings, but also that there are positive or negative valences attached to the terms themselves. ${ }^{76}$ Although in the eighteenth century, relatively few theorists were willing to be identified as proponents of "democracy," in the twenty-first century, its desirability is taken as a given, especially in what we still call "the West." existing countries by the degree to which they are sufficiently "democratic" and, perhaps, even to intervene and overthrow existing leaders in the name of furthering "democracy." 78 So something rides, practically speaking, on whether a particular system is identified as "democratic" or "undemocratic;" it is not surprising, then, that partisans of one or another particular country (including the United States, of course) will fix on self-serving definitions of "democracy," even as their adversaries proclaim what may be quite different (and perhaps equally self-serving) alternatives.

But I also want to say some specific things about "functionality" and "dysfunctionality." Any supporter of an existing political order wants to be able to describe it as "functional," even as opponents will claim just the opposite. Your eminent Yale colleague David Mayhew is famous for arguing that Congress is far more functional than many of us believe, and he proffers as evidence the fact that even in times of divided government it is able to pass legislation, some of it quite important. ${ }^{79}$ In his 2013 book, Partisan Balance: Why Political Parties Don't Kill the U.S. Constitutional System, ${ }^{80}$ he simply lists an impressive number

75. See generally W.B. Gallie, Essentially Contested Concepts, in 56 ProceEdings OF THE ARISTOTELIAN SOCIETY 167 (1955-1956).

76. Id.

77. See generally Katznelson, supra note 1.

78. J. Dana Stuster, Mapped: The 7 Governments the U.S. Has Overthrown, ForEIGN POL'Y (Aug. 20, 2013), http://foreignpolicy.com/2013/08/20/mapped-the-7-governments-the-u-s-hasoverthrown/ [https://perma.cc/3XK4-BWKZ].

79. See generally David R. Mayhew, Is Congress "the Broken Branch?," 89 B.U. L. Rev. 357 (2009).

80. See generally David R. Mayhew, Partisan Balance: Why Political Parties Don't 
of bills that were passed during the 1980s and 1990s, when neither Democrats nor Republicans were able to gain control of both branches of Congress plus the White House.$^{81}$ No one should ever dispute the accuracy of Mayhew's numbers; he knows an almost unimaginable amount about American politics. That being said, though, I have in my own book, Framed, criticized Mayhew, who regards the list as a "knock-down argument," for being insufficiently attentive to the extent to which the legislation he cites can be said truly to have confronted in satisfactory measure the depth of the challenges facing us as a country. ${ }^{82}$ Not all legislation, obviously, is good legislation.

And even Mayhew, incidentally, has agreed that the contemporary Congress is quite different in major respects from that of the halcyon days of the 1980s and 1990 s, for by any account far less legislation is being passed ${ }^{83}$ The Voice of America News itself reported in December 2013 that "[ $[$ ] $]$ he 113th Congress has been the least productive in history, with the House and Senate passing only 57 bills that were signed into law by President Barack Obama," ${ }^{84}$ and it correctly predicted that things would get no better in the election year of $2014 .{ }^{85}$ Republicans, of course, took over the Senate in $2015 .{ }^{86}$ To be sure, Congress toward the end of 2015 was able to pass a bill designed to keep the government functioning without another shutdown, ${ }^{87}$ but this is surely to adopt an absolute minimal standard for what counts as congressional functionality. Indeed, the Republican Senate during 2016 is perhaps most noteworthy for quite literally refusing to hold a single day of hearings on the nomination by President Obama of Judge Merrick Garland to succeed Antonin Scalia, who had died in February of $2016 .{ }^{88}$

In any event, to put on a Band-Aid may count, from one perspective, as

KiLl the U.S. Constitutional System (2011).

81. Id. at 69.

82. SAnford Levinson, Framed: America's Fifty-One Constitutions And the Crisis OF GOVERnANCE 235 (2012).

83. David R. Mayhew, The Least Productive Congress in History?, Politico (Dec. 23, 2013), http://www.politico.com/magazine/story/2013/12/least-productive-congress-in-history$101476 ? \mathrm{o}=0$ [https://perma.cc/JT7P-WVK9].

84. Cindy Saine, US Congress in 2013 Passes Fewest Laws in History, Volce OF AM. (Dec. 20, 2013, 12:19 AM), http://www.voanews.com/content/us-congress-2013-passes-fewest-laws-inhistory/1814234.html [https://perma.cc/FNR6-YF34].

85. Id.

86. Stephen Collinson, Republicans Seize Senate, Gaining Full Control of Congress, CNN (Nov. 5, 2014, 10:43 AM), http://www.cnn.com/2014/11/04/politics/election-day-story/ [https:// perma.cc/XJ7T-E6WR].

87. Erin Kelly, Obama Signs Funding Bill Averting Government Shutdown-for Now, USA TODAY (Sept. 30, 2015, 9:55 PM), http://www.usatoday.com/story/news/2015/09/30/senateapproves-funding-bill-avert-government-shutdown/73032366 [https://perma.cc/NN28-CUG4].

88. See, e.g., Eric Black, Senate Norms on Supreme Court Nominations: We're Entering Uncharted Territory, https://www.minnpost.com/eric-black-ink/2016/10/senate-norms-supremecourt-nominations-were-entering-uncharted-territory [https://perma.cc/NY8H-C7EN]. 
responding to an injury, but if major surgery is actually required, it would be quixotic to offer the Band-Aid as evidence of a sufficient medical response. To be sure, we may be far more often confident about medical diagnoses and treatment plans than about politics. We often disagree about our most basic descriptions of the political world (is there really a phenomenon called "global warming" and, even if there is, is there a causal connection with presumptively changeable behavior by human beings?); even if we agree on the descriptions, we can then engage in almost endless political warfare about what count as adequate responses. We are increasingly likely to disagree on the treatment plans, often combining at that stage particularly both factual assertions- "it will never work, or, indeed, be counterproductive"-with value statements as well— "it might work, but only at the price of depriving us of our liberty or our prosperity."

In any event, it should be absolutely clear that one simply cannot present a neutral notion of "functionality" or "dysfunctionality" without at the very same instant taking a political position. The Affordable Care $\mathrm{Act}^{89}$ is a fine example of governmental functioning at its best if and only if one agrees with enough of its factual and value premises. Ditto your own example of the "solution" to the Debt Ceiling Crisis of $2011,{ }^{90}$ which gave us, among other things, the lunatic "policy" (scare quotes intended) of "the sequester," "w1 which takes a cleaver to almost all government programs.

It is true, though, that I am mixing up two decidedly different notions of "functionality" and "dysfunctionality," and you are right to call me out on it. That is, with regard to the American polity since the takeover of the House by Republicans in $2011,{ }^{92}$ a basic reality is the near-impossibility of passing any significant legislation. ${ }^{93}$ We have embraced a culture of low expectations by giving Congress credit for managing, at the last minute, to prevent defaulting on the national debt, even though the machinations required to avoid default triggered a lowering by Standard and Poor's of the credit-worthiness of the United States from the "gold standard" AAA to AA+. ${ }^{94}$ And in doing so,

89. Patient Protection and Affordable Care Act, Pub. L. No. 111-48, 124 Stat. 119 (2010) (codified as amended in scattered titles of the U.S.C.).

90. See Budget Control Act of 2011, Pub. L. No. 112-25, 125 Stat. 240 (codified as amended in scattered titles of the U.S.C.).

91. Suzy Khimm, The Sequester, Explained, WASH. Post: WonkBlog (Sept. 14, 2012), https://www.washingtonpost.com/news/wonk/wp/2012/09/14/the-sequester-explained [https://perma.cc/Q97K-5KH9].

92. Douglas Stanglin, Election Day 2010: GOP Wins House, Democrats Retain Senate, USA TODAY (Nov. 3, 2010), http://usatoday30.usatoday.com/news/politics/2010-11-03-RW_ mainelection02_ST_N.htm [https://perma.cc/82PH-JZ3J].

93. See, e.g., Philip Bump, The 113th Congress Is Historically Good at Not Passing Bills, WASH. Post (July 9, 2014), https://www.washingtonpost.com/news/the-fix/wp/2014/07/09/the113th-congress-is-historically-good-at-not-passing-bills [https://perma.cc/KQ3F-MX9V].

94. Zachary Goldfarb, S\&P Downgrades U.S. Credit Rating for First Time, WASH. Post (Aug. 6, 2011), https://www.washingtonpost.com/business/economy/sandp-considering-firstdowngrade-of-us-credit-rating/2011/08/05/gIQAqKeIxI_story.html [https://perma.cc/GDL4-P8DB]. 
incidentally, Standard and Poor's referred not to the weakness of the U.S. economy, still the world's strongest, but, rather, to doubts that had developed about the adequacy of our political system..$^{95}$ They were correct.

So take your question: Would the election of, say, Ted $\mathrm{Cruz}^{96}$ bring "functionality" back to American politics by leading to the passage of all sorts of wondrous legislation by an invigorated Republican majority in the House and Senate that would eagerly be signed by President Cruz? The answer is clearly yes, if all we mean by functionality is the ability of Congress to pass legislation. Perhaps this is the equivalent of praising the German army for functioning so well in the blitzkrieg of 1939 , when it quickly conquered Poland.${ }^{97}$ But, obviously, the second, and perhaps more controversial, aspect of defining "functionality" and "dysfunctionality" now comes into play, for we must necessarily ask what actually is being achieved, whether by legislation or by armies. Or, perhaps, we must recognize that functionality along one dimension, whether legislative or military, must be placed within the context of the wider system and the extent to which the functionality in a limited domain leads overall to what we regard as a "functional" or "dysfunctional" political order. Still, even there, values will necessarily come into play. Surely most of us believe that Germany became a "dysfunctional" political order well before late 1944 and 1945 when its leaders recognized that they had so totally lost control of events that unilateral surrender (and suicide) were the only viable options. ${ }^{98}$ For some of us, a "unitary government" fashioned by a Cruz-dominated Republican coalition would be enough to despair about the future of the United States (and the world) and to entertain thoughts not only of emigration, but, far more seriously, of secession. Why would we expect Pacifica, composed of California, Oregon, and Washington, perhaps joined by Hawaii, to remain within such a Union? ${ }^{99}$ A serious secessionist movement, as distinguished from the "let's pretend" versions that are rife within the United States would, presumably, be evidence of dysfunctionality. But is that what it would take to overcome your argument that the Cruz regime, however obnoxious, would demonstrate a capacity to govern that would overcome the "dysfunction"-oriented analyses like my own?

\section{II. "REPRESENTATION" AND "DEMOCRACY"}

I begin with the titles of two books of mine: Our Undemocratic Constitution:

95. Id.

96. Or, as subsequently happened, Donald J. Trump.

97. Raymond Limbach, Blitzkrieg, EnCYClopedia Britannica (Apr. 23, 2015), https://www.britannica.com/topic/blitzkrieg [https://perma.cc/MC9A-XSJX].

98. See generally Christian Goeschel, Suicide at the End of the Third Reich, 41 J.CONTEMP. Hist. 153 (2006).

99. For such an argument following the 2016 triumph of Donald Trump, see Donny Kwiksotik, Time for the Left Coast to SECEDE. It Is Possible! Here's How. \#Calexit!, DAILY Kos (Nov. 10, 2016), http://www.dailykos.com/story/2016/11/10/1595709/-Time-for-the-Left-Coast-toSECEDE-It-is-possible-Here-s-how-Calexit [https://perma.cc/63GH-BMTY]. 
Where the Constitution Goes Wrong (and How We the People Can Correct It) (100 $^{10}$ and then Framed: America's 51 Constitutions and the Crisis of Governance. ${ }^{101}$ The first one, obviously, addresses whether the Constitution of 1787 , left remarkably unamended in relevant structural aspects, could possibly be described as democratic using fairly standard-form, twenty-first century standards of democracy. ${ }^{102}$ My answer is a resolute no, where the basis of comparison is not only other constitutions from around the world, but, far more relevantly, the constitutions of the fifty states, all of which are arguably more democratic than their national counterpart. ${ }^{103}$ But the response to that book led me to the conclusion that for most people their response was the equivalent of "so what?" Many correctly pointed out that the framers were scarcely twenty-first century Democrats and that was really fine. As the John Birch Society put it in the 1960s, "We're a republic, not a democracy, and let's keep it that way." "104 Even more to the point, for many, is that our system was working quite well_ or at least "good enough" - to warrant praise rather than snarky condemnation based on essentially contested conceptions of "democracy." The word "democracy" is capable of describing a house of many with many differently-hued rooms, and what obtains in the United States is certainly one of them, even if my own taste is considerably different.

Thus the change in the later book, with its emphasis on "the crisis of governance." 105 That there is such a crisis seems to be widely agreed; this is just what it means to express deep worry about the "dysfunctionality" of the American political system. But you describe at least some elements of this crisis as likely to be quite transient, as discussed above. Still, it might well be the case that a more "democratic" system, defined for our purposes as one in which the national government faithfully reflects the policy views of electoral majorities inasmuch as the minority no longer enjoys access to veto points that can block the instantiation of these views, would itself generate such unhappiness as to lead to a far deeper crisis of governance. This could be achieved by any genuine movement toward secession or the greater frequency of mass movements coupled literally with rioting in the streets. Regime change is no small matter, especially if the proposed changes are deep and pervasive rather than relatively marginal. The Reagan Revolution looks quite tame compared with the visions of the Freedom Caucus ${ }^{106}$ within the House of Representatives and others who might

100. SANFord LeVinson, Our Undemocratic Constitution: Where the Constitution Goes Wrong (And How We the People Can Correct It) (2006).

101. LEVINSON, supra note 82.

102. See generally LEVINSON, supra note 100.

103. See generally id.

104. Gilbert Abcarian \& Sherman M. Stanage, Alienation and the Radical Right, 27 J. PoL. 776, 780 (1965).

105. See generally LEVINSON, supra note 82 .

106. Tim Dickinson, Meet the Right-Wing Rebels Who Overthrew John Boehner, Rolling STONE (Oct. 6, 2015), http://www.rollingstone.com/politics/news/meet-the-right-wing-rebels-whooverthrew-john-boehner-20151006 [https://perma.cc/42E6-HQ5H]. 
demand a great deal of effective say should a Republican win the White House in 2016 .

As the great Robert Dahl argued many years ago, democracy of the American type, i.e., comprised of great numbers of diverse citizens (and, for that matter, non-citizens), is always subject to the problems posed by groups who are intensely antagonistic to one another and therefore indisposed to the compromises that are thought to be necessary to pluralistic polities. ${ }^{107}$ To overcome these baleful possibilities, Dahl took refuge in the reality of "cross-cutting" cleavages, where individuals were members of many different groups and organizations that would put them in contact with individuals like them in some respects-their liking for public support of culture, whether high or low-and very different in others, such as their relative support for reproductive choice as against the right to life. ${ }^{108}$

It has certainly been argued that an important development over the past several decades, even as the total American population has in many ways become ever more diverse, is the diminution of such cross-cutting cleavages. People seem to be sorting themselves out more by reference to their major modes of identification, even without conscious political gerrymandering that reduces the possibility that centrist voters, pulled in different directions by their cross-cutting associations, will dominate the electoral process. Perhaps the most vivid evidence of this was provided by electoral maps following the 2012 presidential election. Relatively few counties or, for that matter, congressional districts, were divided 51-47\% between Barack Obama and Mitt Romney, even though that was the national vote percentage. ${ }^{109}$ States themselves deviated quite dramatically, of course. Texas, for example, where I live, gave $57.2 \%$ of its votes to Romney. ${ }^{110}$ But even within Texas, very few counties tracked the state-wide percentages. ${ }^{111}$ Instead, Travis County, the home of the University of Texas, where I teach, gave $60.2 \%$ of its votes to Obama ${ }^{112}$ even as most other counties were giving seventy and even eighty percent of their votes to Governor Romney. ${ }^{113}$ In the battleground state of Ohio, won by Obama with $51.1 \%$ of the popular vote, Obama obtained

107. See Robert Dahl, Pluralist Democracy in the United States: Conflict and CONSENT 338-39 (1968).

108. See id.

109. David Nir, Daily Kos Elections' Presidential Results by Congressional District for the 2016 and 2012 Elections, DAILY Kos (Nov. 19, 2012, 12:30 PM), http://www.dailykos.com/ story/2012/11/19/1163009/-Daily-Kos-Elections-presidential-results-by-congressional-district-forthe-2012-2008-elections [https://perma.cc/3AAW-6T2L].

110. Texas: Romney vs. Obama, REAL CLEAR POL., http://www.realclearpolitics.com/epolls/ 2012/president/tx/texas_romney_vs_obama-1945.html [https://perma.cc/CK3N-3XWP] (last visited Nov. 8, 2016).

111. 2012 Texas Presidential Results, Politico (Nov. 19, 2012, 2:48 PM), http://www. politico.com/2012-election/results/president/texas/ [https://perma.cc/SJL9-37K4].

112. Id.

113. 2012 Ohio Presidential Results, Politico (Nov. 19, 2012, 2:48 PM), http://www.politico. com/2012-election/results/president/ohio/ [https://perma.cc/E88C-Q89J]. 
sixty-eight percent of the vote in Cuyahoga County (Cleveland) and sixty percent of the vote in Franklin County (Columbus), though Romney carried a number of far smaller, rural counties by even more impressive margins. ${ }^{114}$ These differences within states also help to explain the particular reality of the modern House of Representatives and the importance, for example, of the call by Fair Vote for repealing the congressional statute, dating back to 1842 , that mandates singlemember districts and replacing it with one that requires relatively large states (those with, say, more than nine representatives) to elect them in multi-member districts using proportional representation). ${ }^{115}$ Among other things, this brings home the degree to which our very definition of "majority rule" (assuming we think that such rule is a good thing) is created in part by formal institutions and the incentives they generate with regard, for example, to the creation and maintenance of our particular two-party system.

But what this also suggests, among other things, is the tension within American political and constitutional thought between adhering to the wishes of majorities-even if those wishes are, as Justice Holmes put it in his Lochner dissent, "tyrannical"116 - and instead being disciplined by the demands of overarching constitutional norms or what Publius repeatedly invoked in The Federalist as "the public good"117 (or Michael Sandel, a leading contemporary proponent of "civic republican" politics, describes as "the common good"118). Yet, as many people, including Dahl, have pointed out, Publius is Janus-faced, for he also emphasized the ubiquitous elements of self-seeking and raw ambition as constituting our politics, and he ultimately relied more on "ambition counteracting ambition" than on the homilies contained in "parchment barriers," including the Bill of Rights, to discipline political leaders. ${ }^{119}$

$\mathrm{We}$ are, even as we are engaging in this exchange, observing the playing out of these different versions of politics in the chaos enveloping the House of Representatives and sparked by Boehner's resignation. ${ }^{120}$ Publius was desperately trying to prevent the creation of a party system, a system that, by definition, means members of a given party must on occasion subordinate their own notions of the public interest to the interests of their party. ${ }^{121} \mathrm{He}$ failed completely and unequivocally, with mixed consequences. There are many good reasons to have political parties; furthermore, no serious person believes in the possibility of truly

114. Id.

115. Tory Mast, Seeking Fair Representation Before Full Representation, FAIR VoTE, http://archive.fairvote.org/?page=526 [https://perma.cc/7JB2-7XEC] (last visited Nov. 11, 2016).

116. Lochner v. New York, 198 U.S. 45, 75 (1905) (Holmes, J., dissenting).

117. See generally The Federalist No. 10 (James Madison) (Isaac Kramnick ed., 1987).

118. See Natan Doran, Michael Sandel and the Politics of the Common Good, FABIAN Soc'Y (Sept. 21, 2012), http://www.fabians.org.uk/michael-sandel-and-the-politics-of-the-common-good/ [https://perma.cc/3VA7-TK8B].

119. See The Federalist No. 48, at 51 (James Madison) (Isaac Kramnick ed., 1987).

120. See Manu Raju \& Deirdre Walsh, Why John Boehner Quit, CNN(Oct. 7, 2015, 5:00 PM), http://www.cnn.com/2015/09/25/politics/why-john-boehner-quit/ [https://perma.cc/HW9W-TYRD].

121. See The Federalist No. 10 (James Madison) (Isaac Kramnick ed., 1987). 
non-partisan politics. Perhaps this is not true for the partisans of particular monarchs or dictators who argue that they have remarkable capacities for discerning the needs of their people. ${ }^{122}$ Benevolent despotism is still alive and well as a theory, even if there are few advocates. ${ }^{123}$ But we must recognize that there is no such thing as a free lunch, and partisan politics certainly brings defects to government, sometimes very serious ones. These defects must be tamed by some notion of subordination to a general good, even at the cost of party advantage in the next election.

There is literally no reason to default on our debt or for the government to shut down in December (or anytime else). If we were a parliamentary government or even a system that recognized the existence of multiple parties within the House of Representatives, the Speaker's resignation would signal that there was a reorganization of the ruling coalition. ${ }^{124}$ It was surely not unthinkable, even if improbable, that John Boehner could have retained his Speakership until January 3, 2017 simply by entering into a coalition with Nancy Pelosi and House Democrats, together with thirty Republicans who announce themselves to be members of the National Patriotic Party, a group that recognizes the United States simply cannot afford to pay the price demanded by the Freedom Caucus and its allies. $^{125}$ One might expect these hypothetical thirty members to be disproportionately drawn from the ranks of those who have already announced their intention not to run for re-election in 2016. Such a coalition would require significant compromise by both Pelosi and the Democrat majority, on the one hand, and the Republican colluders, on the other. But, as with the terms of any future end to the conflict in the Middle East between Jewish Israelis and Palestinians, the basic outline of a deal is already quite well known. ${ }^{126}$ The question is whether there are leaders willing to stake their futures (and perhaps literal lives) on agreeing to the terms.

\section{THE "HARD-WIRED CONSTITUTION" (OR THE Constitution of Settlement)}

You continue to be far more optimistic than I am that the United States can escape from its winter, spring, summer, and fall of its discontents by ingenious (or ingenuous) "workarounds" of the more dismal features of the system

122. But see Natasha M. Ezrow \& Erica Frantz, Dictators and Dictatorships: Understanding Authoritarian REgimes AND THEIR LEADERS 12-13 (2011).

123. Id. at 8-9.

124. See John D. Huber, The Vote of Confidence in Parliamentary Democracies, 90 Am. PoL. SCI. REV. 269, 269-70 (1996).

125. See Elena Schneider, The GOP Establishment Strikes Back, Politico (Oct. 5, 2016, 3:00 PM), http://www.politico.com/story/2016/08/gop-establishment-strikes-back-house-freedomcaucus-226997 [https://perma.cc/XJ7K-ZENK].

126. See generally David C. Unger, The Inevitable Two-State Solution, 25 WORLD PoL'y J. 59, 59-60 (2008) (discussing the seemingly inevitable compromise to the Israeli-Palestinian conflict). 
bequeathed us in Philadelphia and left quite impervious to change because of the truly dreadful Article V that structures constitutional amendment itself. You refer to Steve Griffin's excellent new book, ${ }^{127}$ and one of Steve's suggestions is that we would be far better off as a political (and constitutional) order if the national government enjoyed the same opportunity that the citizenry of many American states (and foreign countries) do to engage in at least some measure of direct democracy through the initiative and referendum. ${ }^{128}$

I will not rehearse all of my arguments as to why constitutional reform might be both necessary and proper. As the dedicatee of Framed, you are well aware of all of my arguments, and readers can obviously track them down with ease. ${ }^{129}$ What I do wish to assert, in ending my second missive in this exchange, is that the very worst consequence of Article $\mathrm{V}$ is that it has infantilized our politics by making it impossible, as a practical matter, to have serious discussions about constitutional reform. ${ }^{130}$ Frankly, only zealots would devote their scarce time, money, and energy to proposals necessitating constitutional change. The "amendment game" is simply stacked too much in favor of the status quo. ${ }^{131}$ Elizabeth Warren speaks of the game being "rigged" with regard to banks and certain business corporations $;{ }^{132}$ this is even truer with regard to the Constitution itself. If one is faced with rigged games, the most rational response, assuming that revolutionary overthrow is impossible, is simply to do something else and to tell oneself that the game is not really all that important anyhow.

I do not think that waiting until January to inaugurate a new President is the most serious weakness in the Constitution; only a true zealot could possibly think that. But I do think that you underestimate the potential costs of the hiatus that has regularly been inflicted on the country where an insurgent candidate either defeats the incumbent (Roosevelt in 1932, ${ }^{133}$ Reagan in $1980^{134}$ ) or decisively defeats the coalition presided over by the incumbent, even if he is not formally

127. See generally GRIFFIN, supra note 40 .

128. Id. at 75 .

129. See LEVINSON, supra note 82.

130. Id.

131. Id.

132. See Zach Carter, Elizabeth Warren: American Justice is 'Rigged' in Favor of the Rich, HuFFINGTON POST (Oct. 6, 2016, 12:00 PM), http://www.huffingtonpost.com/entry/elizabethwarren-american-justice-rigged-for-rich_us_56b205a2e4b04f9b57d7e5fe[https://perma.cc/9G894ESZ].

133. See Kenneth T. Walsh, The Most Consequential Elections in History: Franklin Delano Roosevelt and the Election of 1932, U.S. NEws (Oct. 6, 2016, 4:00 PM), http://www.usnews.com/ news/articles/2008/09/10/the-most-consequential-elections-in-history-franklin-delano-rooseveltand-the-election-of-1932 [https://perma.cc/HW9W-TYRD].

134. See Kenneth T. Walsh, The Most Consequential Elections in History: Ronald Reagan and the Election of 1980, U.S. News (Oct. 6, 2016, 4:15 PM), http://www.usnews.com/news/ articles/2008/09/25/the-most-consequential-elections-in-history-ronald-reagan-and-the-election-of1980 [https://perma.cc/FHQ9-ARPX]. 
on the ballot (Lincoln in $1860,{ }^{135}$ Clinton in $1992,{ }^{136}$ Obama in $2008^{137}$ ). It is no small matter for the United States to have an ineffective President in the time between the discredited incumbent and the legitimate insurgent. But even something so banal as moving up Inauguration Day is undiscussed and thought impossible. The reason may simply be that it would necessarily require confronting the perverse Electoral College, opposed by every Gallup poll taken since $1944,{ }^{138}$ but still structuring our presidential elections and creating the dreadful phenomenon of battleground states that distort our entire polity. ${ }^{139}$ It is true, as you point out, that the Electoral College could in effect be neutralized through adoption of the Fair Vote proposal by which the ten largest states would agree to allocate their votes to the winner of the popular vote. ${ }^{140}$ It is worth noting though that it would not at all affect the potential costs of the delayed inauguration, even if one stilled any doubts about the wisdom of the Fair Vote proposal itself (which does not, importantly, require that the "winner" in fact demonstrate majority support as against simply coming in first past the post in the national totals). ${ }^{141}$

The real point is that I almost desperately want a national conversation about the weaknesses - and strengths - of our basic constitutional system and the degree to which the rigidities of the written Constitution, coupled with what Ferejohn and Eskridge have termed "constitutionalized statutes," 142 including, for example, the requirement of single-member districts, require explicit textual

135. See Mallie Jane Kim, The Election That Led to Civil War, U.S. News (Oct. 6, 2016, 4:20 PM), http://www.usnews.com/opinion/articles/2010/12/02/the-election-that-led-to-the-civil-warmallie-jane-kim [https://perma.cc/7UJ6-H5KM].

136. See Robin Toner, The 1992 Elections: President-The Overview; Clinton Captures Presidency with Huge Electoral Margin; Wins a Democratic Congress, N.Y. TIMEs (Oct. 7, 2016, 6:00 PM), http://www.nytimes.com/1992/11/04/us/1992-elections-president-overview-clintoncaptures-presidency-with-huge.html?pagewanted=all [https://perma.cc/RT8Y-ZTY3].

137. See Adam Nagourney, Obama Wins Election, N.Y. Times (Oct. 7, 2016, 6:20 PM), http://www.nytimes.com/2008/11/05/us/politics/05campaign.html [https://perma.cc/NLV9-TL83].

138. Lydia Saad, Americans Call for Term Limits, End to Electoral College, Gallup (Jan. 18, 2013), http://www.gallup.com/poll/159881/americans-call-term-limits-end-electoralcollege.aspx [https://perma.cc/5FJV-69WP].

139. See Portrait of a Swing State, Daily EMERAld (Oct. 7, 2:15 PM), http://www. dailyemerald.com/2004/10/04/portrait-of-a-swing-state/ [https://perma.cc/CEZ3-G8RY]. Obviously, we also learned in 2016 that the electoral vote could lead to a candidate who received only $46 \%$ of the popular vote, and 2.5 million fewer actual votes than his opponent, could nonetheless become President.

140. See The Electoral College, FAIR VOTE (Oct. 7, 2016), http://www.fairvote.org/the electoral_college\#how_the_electoral_college_works_today [https://perma.cc/A5CP-L9FJ].

141. See Gary Greg, Electoral College Keeps Elections Fair, PoLiTico (Oct. 7, 2016 3:00 PM), http://www.politico.com/story/2012/12/keep-electoral-college-for-fair-presidential-votes084651 [https://perma.cc/6VAA-2VS2].

142. See William N. Eskridge Jr. \& John Ferejohn, Super-Statutes, 50 DukE L.J. 1215, 1216 (2001). 
amendment and not simply clever workarounds. We would be having such conversations - and possibly even conventions - if, like fourteen states in the Union, ${ }^{143}$ the Constitution's text mandated that the electorate be given the opportunity, at stated intervals (usually ten or twenty years) to vote on whether or not to have a new constitutional convention. ${ }^{144}$ Perhaps it is a bit like an assisted suicide statute; one may very well never use the life-ending drug supplied by a physician, but it is a great comfort to know the possibility is there and that, therefore, one is more genuinely in control of one's life, including the inevitable leave-taking. Whatever the promise of the Constitution's Preamble about the importance of "We the People," would feel much better if the citizenry were not forced to continue living under a greatly defective Constitution because our doctors, in 1787, deprived us of an effective way of reasserting our own collective autonomy.

I will stop for now, secure in the belief that you will offer thoughtful responses to all of these points.

Sandy

November 1, 2015

Dear Sandy:

You freely acknowledge that your view that our constitutional system is dysfunctional is shaped by your political preferences. We might compare your approach to constitutional dysfunction to that of the Progressives in the early twentieth century. Their demand for constitutional reform was propelled by a substantive agenda, combined with the sense that the old Constitution blocked desirable change. The Progressive political scientist Henry Jones Ford famously spoke of the Progressive vision of the presidency as "the work of the people, breaking through the constitutional form." break through our present-day constitutional forms to reenergize government and achieve reforms that, in your opinion, the country desperately needs.

Of course, as soon as you link your calls for constitutional reform to a particular (progressive) substantive agenda, you will likely lose support from people who do not agree with your politics. And that may make it very hard to

143. See Ala. Const. art. XIII, § 3; see also Mandatory Vote About Whether a Statewide Constitutional Convention Shall Be Held, BALLOTPEDIA, https://ballotpedia.org/Mandatory_vote_ about_whether_a_statewide_constitutional_convention_shall_be_held [https://perma.cc/6LKGV4M7] (last visited Nov. 11, 2016).

144. Id.

145. U.S. CONST. pmbl.

146. Richard J.Ellis, The Development of the American Presidency 14 (2012) (quoting Henry Jones Ford, The Rise and Growth of American Politics 292-93 (1898)). 
obtain supermajority support in Congress and in the states.

As you have pointed out, Tea Party conservatives are also quite interested in constitutional reform. ${ }^{147}$ They simply seek different reforms than you do, and with different ends than yours. Nevertheless, what you and the Tea Party share is the belief that constitutional reform is not inconsistent with the best parts of the American political tradition. ${ }^{148}$ Quite the contrary, as Publius argues in the opening essay of The Federalist, making our system of government a matter of "reflection and choice" is and should be the most characteristically American enterprise. ${ }^{149}$ But where many Tea Party acolytes regard much of twentieth century constitutional development as a mistake and seek a kind of constitutional restoration, you hope to move the Constitution in an even more Progressive (in both senses of the word) direction.

This helps explain your view that a unified federal government under the leadership of the current Republican Party might be dysfunctional under your definition of that term. Offering a comparison to the German blitzkrieg at the beginning of World War II, you argue that political efficiency in the service of a disastrous political agenda is not an efficiency worth having. Yet this concern is the classic justification for the very features of our constitutional system that you would like to reform. The American Constitution has multiple veto points and checks and balances precisely to prevent the kind of calamity that you fear would occur if your political adversaries were able to work their will without restraint. So it is a bit odd for you to offer these concerns in your explanation of why our constitutional system is dysfunctional. Put another way, I do not think one can simultaneously argue that the Constitution is dysfunctional if it prevents progressives from pursuing agendas that they believe are in the public interest, but that it is also dysfunctional if it fails to prevent conservatives from pursuing their agendas.

But perhaps there is a better way to make your point. You suggest that if a firebrand like Ted Cruz were elected in 2016, and if the Republicans retained majorities in both Houses of Congress, liberal states in the Pacific West might consider secession. A central function of a constitution is, as I like to say, to "make politics possible." ${ }^{150}$ A well-functioning constitution establishes a political order that gives people incentives to resolve their disputes through politics and protest rather than through violence and civil war. ${ }^{151}$ So, you might argue, if significant parts of the country have lost faith that they will eventually be able to get a fair shake through ordinary politics, there is something deeply wrong with the Constitution. And if a constitution can not keep a political union together, it

147. See generally Christopher W. Schmidt, The Tea Party and the Constitution, 39 HASTINGS Const. L.Q. 193 (2011) (discussing the Tea Party as a constitutional movement).

148. $I d$.

149. The Federalist No. 1, at 87 (Alexander Hamilton) (Isaac Kramnick ed., 1987).

150. Jack M. Balkin, The Framework Model and Constitutional Interpretation, in Philosophical Foundations of Constitutional LaW 241, 242-43 (David Dyzenhaus \& Malcom Thorburn eds., 2016).

151. Id. at 243 . 
is to that extent a failure. Thus, the argument might go, the problem is not that you find the policies of a unified Republican government objectionable. Rather, the problem is that such a government will lead to dissolution of the Union, which is evidence of constitutional failure. In the same way, you might point out, even if Abraham Lincoln's election in 1860 was a very good thing for the United States, the fact that various states seceded in 1861 is proof that the 1787 Constitution had failed at its most central function.

Fair enough. But I think that there is very little evidence that any part of the country would attempt to secede-much less actually achieve independence-if the Republican Party gained the presidency and both Houses of Congress, as it did only a decade ago during George W. Bush's Administration. One of the most interesting features of our present polarized politics is how remarkably little widespread political unrest there has been to date. (I include protests against police misconduct by groups like Black Lives Matter.) Moreover, even if the Pacific states wanted to leave, it is simply not feasible for a superpower like the United States to permit a potentially hostile country to form on its western border, especially if that country would retain a powerful military and any degree of nuclear power. I think it is safe to say that, at least at this point in its history, the United States will not consent to the exit of any state from the Union. Of course, this may change in the future, but it would be under very different circumstances-when the United States was so debilitated that it was no longer a major world power and could no longer enforce its will within its own borders. For example, secession might occur if the United States had been successfully invaded by another power, or if an economic crisis left the central government unable to provide basic services to or defend parts of the country. That is not the situation today. For this reason, I do not think you have made the case that a unified government led by Republicans is dysfunctional because it may lead to secession. It may lead to very unwise policies, but those are not the same thing as dysfunction.

One should not, however, let disputes about the concept of dysfunction get in the way of your larger point. You argue that "the very worst consequence of Article $\mathrm{V}$ is that it has infantilized our politics by making it impossible, as a practical matter, even to have serious discussions, at least outside the seminar room, about constitutional reform." ${ }^{" 152}$ I agree with you that it is important for Americans to have serious discussions about constitutional reform, especially in today's circumstances. I disagree with you that Article V stands in the way of serious discussion.

Constitutional reform involves the constituent power of the people-the power of "We the People" - to establish a constitution and alter or amend it. But we should not assume that the constituent power of the people is reserved only to "great and extraordinary occasions," as The Federalist No. 49 puts it. ${ }^{153}$ Rather, much contemporary constitutional theory, including theories that you have championed, argues that the constituent power of the people can be and often is

152. See supra Levinson's letter dated October 12, 2015.

153. The Federalist No. 49, at 313 (James Madison) (Isaac Kramnick ed., 1987). 
exercised outside of Article V. ${ }^{154}$ Both Bruce Ackerman's work on constitutional moments and my work on constitutional construction are premised on the idea that "We the People" engage in constitutional change outside of Article V. Ackerman argues that Americans have worked around the state-centered rules of Article V amendment and developed national models for constitutional amendment. ${ }^{155}$ I have argued that through state-building constructions by the political branches and judicial constructions by the courts, Americans have repeatedly changed the constitution-in-practice. ${ }^{156}$

I believe that you should integrate your earlier work on constitutional amendment with your present work on constitutional design. The two fit together very well.

How is it possible to have constitutional reform without Article V amendment? As I pointed out in my initial response, it is crucial to distinguish between the hard-wired Constitution and the constitutional order. Although the hard-wired Constitution requires Article V amendment, the constitutional order can be altered through many different methods. ${ }^{157}$ These include ordinary legislation, changes in the internal rules of the Senate and House, constitutional workarounds, and state compacts - such as the reform of the Electoral College I mentioned previously. They also include new judicial appointments and new judicial doctrines that might limit or overrule previous decisions and uphold new campaign finance and voting reforms. If America does change its campaign finance and electoral systems, I expect that most of the reforms, if not all of them, will occur outside of Article V amendment.

I do not pretend that every reform to our constitutional system can be achieved outside of Article V. We cannot, for example, move Inauguration Day to the second week of November (although, of course, we could create a set of political conventions that ameliorated the problem if the outgoing and incoming administrations cooperated). But this does not strike me as a major source of our current difficulties. Rather, as discussed in my first essay, our most pressing problems concern our system of representation. We can address most of these through the methods of constitutional construction I have listed above. And many other problems that we currently associate with political dysfunction will recede as we transition to a new constitutional regime.

My central disagreement with your approach is that you too easily run together constitutional reform with Article $\mathrm{V}$ amendment or with a new constitutional convention. Doing so exacerbates the very problem of "infantilization" that you complain about. It leads people to believe that they can only change their political institutions through Article $V$ or through a new convention, which, in turn, leads to despair and resignation. Yet constitutional

154. Sanford Levinson, Jack Balkin as the Picasso of Constitutional Theorists, 2012 U. ILL. L. REV. 711, 716 .

155. See generally 1 Bruce Ackerman, We the People: Foundations (1991) [hereinafter Ackerman, 1 We the People].

156. See Jack M. Balkin, Living Originalism 10, 21-22, 70-71, 305-12 (2011).

157. Balkin, supra note 16, at 1162-63. 
reform is not the same thing as Article V amendment. Amendment is only one path. If you actually want constitutional reform to move outside of the seminar room and into political discussion, you should accept and emphasize this way of framing the issue.

Although the nation seems mired in gridlock, political conditions are not permanent. They change. This fact should give us hope that it is worth making the effort. Even if progress is slow at first, the course of American history demonstrates, over and over again, that political persistence can pay off. And when change comes, it is often rapid, although the previous struggles and preparations that make change possible often take many years. The reforms of the Progressive Era were many decades in the making; so too were the changes of the New Deal and the Civil Rights Revolution. Some of the political reforms our country needs will come through Article V amendment; but many, perhaps most, will not. That is the central lesson that people should draw from our history.

There is no reason why Americans should despair that their generation cannot also be one of great achievement. You have often pointed out, correctly, that blind reverence for the Constitution is a great failing. ${ }^{158}$ But faith in the possibility of progress is not blind reverence; and faith in the adaptability of our constitutional system is our greatest asset.

Jack

August 1, 2016

Dear Jack,

The first thing the reader will notice, of course, is that our first two letters were written within what Aristotle might have called a relative unity of time, ${ }^{159}$ whereas this new exchange begins more than a full eight months later than your November 1st response to my prior letter. Even more important than the lag per $s e$ is the fact that we are now writing after the conclusions of the Republican and Democratic national conventions and their respective nominations of Donald Trump and Hillary Clinton for the presidency. ${ }^{160}$

To put it mildly, much has happened since what now appear the almost halcyon days of November, when we were in Indianapolis. As John Lennon is to

158. LEVINSON, supra note 54, at 9 (arguing that people should not have "blind devotion" for the Constitution if it is dysfunctional and undemocratic).

159. See generally Richard T. Urban, All or Nothing at All: Another Look at the Unity of Time in Aristotle, 61 Classical J. 262, 262 (1966) (attributing the concept of the unity of time to Aristotle).

160. Who is Running for President?, N.Y. TIMES (July 26, 2016), http://www.nytimes.com/ interactive/2016/us/elections/2016-presidential-candidates.html [https://perma.cc/Y6NN-RXJQ]. 
have said, "Life is what happens while you're busy making other plans;", 161 one can say with confidence that many of those who made plans as to what the 2016 election would be like, particularly at the presidential level, have found them nearly irrelevant. In Indianapolis, we were talking about whether Paul Ryan could in fact tame the recalcitrant Freedom Caucus within the House. ${ }^{162}$ Should Donald Trump become President, that might literally be the least of Ryan's worries!

By the time these letters are actually published, readers will know how this political drama has ended. Rather than engage in prognostications that will be of little interest several months from now, let me offer some wider-ranging comments on the constitutional significance of the election battle, especially in terms of our overarching debate about the contribution of the Constitution to our political discontents.

I note that I am deeply disappointed (and more than a bit angry) at Bernie Sanders, not for running against Hillary Clinton, whom in fact I supported, but, rather, for posturing as a "political revolutionary" without once, even for a millisecond, suggesting that any serious revolution would require engaging first in what Publius called serious "reflection" about the adequacy of the Constitution in the twenty-first century and then in a collective "choice" to change things, as was done so notably in $1787 .{ }^{163}$ Sanders never bothered to inform his impressionable followers that his promises, whatever their merit, had almost zero chance of actual adoption because of the structures adopted in 1787. What he was doing, in his own way, was imitating Donald Trump, by pretending in effect that presidents could wave magic wands and make things happen. On occasion, as in certain aspects of foreign and military policy, that might be true; with regard to domestic affairs, it is remarkably untrue, as Hillary Clinton learned to her dismay when living in the White House with her husband and attempting to reform the American medical services industry. ${ }^{164}$ She is often criticized for the relative "prose" of her campaign, in contrast to the "poetry" that often characterizes her opponents, whether Obama in 2008 or Sanders or even Trump in $2016 .{ }^{165}$ Mario Cuomo famously declared that one campaigns in poetry, but must govern in prose. ${ }^{166}$ Perhaps she has learned that all "poetry" does is raise expectations that

161. John Lennon, Beautiful Boy (Darling Boy) (Geffen Records 1981).

162. See generally Scott Wong, Speaker Ryan Courts Conservatives, THE HiLl(Jan. 26, 2016, 6:00 AM), http://thehill.com/homenews/house/266890-ryan-seeks-to-court-conservatives [https:// perma.cc/QE44-L8XB] (discussing Speaker Ryan's difficulties reigning in the Freedom Caucus).

163. See Bernie Sanders, The Political Revolution Continues, BERNIE 2016, https://berniesanders.com/political-revolution-continues/ [https://perma.cc/UVQ9-NRL5]; THE FEDERALIST No. 1 (Alexander Hamilton) (Isaac Kramnick ed., 1987).

164. See generally Matthew Carrigan, The Transformation of Going Public: President Clinton, the First Lady, and Health Care Reform, 17 PoL. Comm. 149 (2000) (discussing the failure of the Clinton health care plan and Hillary Clinton's role in promoting the plan).

165. See Doyle McManus, Hillary Clinton's Problem: Too Much Prose, L.A. Times (Feb. 7, 2016, 5:00 AM), http://www.latimes.com/opinion/op-ed/la-oe-0207-mcmanus-clinton-poetry-prose20160207-column.html [https://perma.cc/QRN5-SCPZ].

166. See Elizabeth Kolbert, Postscript: Mario Cuomo (1932-2015), NEw Yorker:News DeSK 
cannot possibly be met, which leads, almost inexorably, to further disillusionment and alienation.

And here is where I continue to ride my hobbyhorse of wanting us to pay attention to the Constitution itself and at least to think of serious constitutional reform. Our overemphasis on the candidates and the promises they make has led us to the over-personalization of politics, the belief that everything will be all right if only we get the right leader or, concomitantly, that what is going wrong can be blamed on the deficiencies of the leaders we have. ${ }^{167} \mathrm{We}$ end up adopting a version of the "great man" (or "woman") theory of history, reinforced by the general emphasis, especially of history written for a general audience, on presidents as heroes or villains.

I do not want to deny the importance of individuals. I do think it was important that we had presidents with the political skills and moral imagination of Abraham Lincoln and Franklin Roosevelt. But I think that we ignore the importance of underlying structures - or, for that matter, of the political cultures and social movements that placed Lincoln and Roosevelt in office and gave them support_ at our peril. I personally view Donald Trump as a narcissistic sociopath who simply must be beaten. It would be an utter calamity for the United States and for the entire world if he became our President. I can imagine all sorts of scenarios that would follow, including the rise of serious secessionist movements in New England or what I call "Pacifica" or a de facto military coup triggered by the justified unwillingness to obey either illegal or disastrously unwise orders from the Commander-in-Chief. It is also easy enough to imagine mass demonstrations or riots, particularly on Inauguration Day, or the unwillingness of the Senate to confirm most of his nominees. I certainly would not want to have Chris Christie or Rudolph Guiliani ${ }^{168}$ as Attorney General, not to mention anyone from Trump's list of potential Supreme Court nominees. ${ }^{169}$ Perhaps the happiest result, from the perspective of Indiana Republicans, would be the quick impeachment of Trump and his replacement by Vice President Pence, ${ }^{170}$ though

(Jan. 1,2015), http://www.newyorker.com/news/news-desk/postscrip-mario-cuomo [https://perma. cc/26LR-Y39G].

167. See generally Sergio Fabbrini, Personalization as Americanization?: The Rise and Fall of Leader-Dominant Government in Western Europe in the Eighties, 32 AM. STUD. INT'L 51, 56 (1994) (discussing America's change to leader-dominated government and the personalization of executive action through the 1970s and 80s).

168. Or, I would now add, Alabama Sen. Jeffrey Beauregard Sessions.

169. Donald J. Trump Releases List of Potential United States Supreme Court Justices, DONALDJTRUMP.COM (May 18, 2016), https://www.donaldjtrump.com/press-releases/donald-j.trump-releases-list-of-names-of-potential-united-states-supreme-c [https://perma.cc/W4UH-3DWG] (Initial list available at the time of this letter was written, but has now been expanded to twenty-one persons. Donald J. Trump Finalizes List of Potential Supreme Court Justice Picks, DONALDJTRUMP.COM (Sept. 23, 2016), https://www.donaldjtrump.com/press-releases/donald-j.trump-adds-to-list-of-potential-supreme-court-justice-picks [https://perma.cc/R676-ZLYK]).

170. See generally Erica Keppler, Republicans Should Call for Donald Trump's Impeachment, HuFFINGTON POST (July 18, 2016), http://www.huffingtonpost.com/erica-keppler/impeachment- 
that, too, would obviously roil the public at large given that there is no reason whatsoever to believe that "We the People" would choose Pence as President in any normal election. ${ }^{171}$

But enough of speculation about the future. What I want to conclude with are some musings answering the following question: Should we really be so completely shocked at the rise of a narcissistic sociopath like Donald Trump as a potential President (rather than, say, candidate for the House or Senate)? I think that Max Weber, the great German political sociologist, has much to teach us in a 1918 essay that he wrote in the aftermath of World War I and the transformation of Germany from an authoritarian monarchy to a presumably more democratic political system. ${ }^{172} \mathrm{Weber}$ suggested that all systems of "direct election by the people of the bearer of supreme power" have within them an impulse (perhaps today, we should use the metaphor of a "gene") toward Caesarism. ${ }^{173}$ It is, of course, a notable truth about the 1787 Constitution that it explicitly rejected proposals for direct election in favor of what I strongly believe to be the inanity of the Electoral College. ${ }^{174}$ But the original theory, if not the played-out reality, of the Electoral College was not so inane. One might imagine the electors as the original superdelegates, ${ }^{175}$ chosen by the legislature or by the electorate to exercise independent judgment as to who would best serve the interests of the Union. ${ }^{176}$ That vision of the Electoral College, whatever one thinks of it, has long since collapsed. Contemporary electors serve no useful purpose as genuine filters between popular sentiment and presidential selection. They are expected simply to mirror the preferences of the majorities in their states (save in Maine and Nebraska, which do not follow the winner-take-all principle, but still give electors

likely-for-a-_b_11023350.html [https://perma.cc/B28J-VGGM] (suggesting republicans should allow Donald Trump to be elected, then impeach him within months, leaving Pence as President).

171. See Clare Foran, The GOP Shouldn't Wish for a Mike Pence 2020 Run, ATLANTIC (Oct. 5, 2016), http://www.theatlantic.com/politics/archive/2016/10/mike-pence-debate-2020presidential-run/503039/ [https://perma.cc/76BZ-CSLJ] (arguing the policies of Pence are against the direction the party had previously decided to take and that he is currently looking good only when compared with Trump).

172. See generally Max Weber, A Biographical View, in From Max Weber: Essays in Sociology 3, 17-22 (H.H. Gerth \& C. Wright Mills trans., 1946), https://archive.org/stream/ frommaxweberessa00webe\#page/n9/mode/2up [https://perma.cc/W2JB-3MF4] (discussing Weber's changing political identity during 1918).

173. Max Weber, Parliament and Government in Germany Under a New Political Order, in Weber: Political Writings 130, 221 (Peter Lassman \& Ronald Spiers eds., 1994).

174. Norman R. Williams, Why the NPVC is Unconstitutional, 2012 BYU L. REV. 1523, 1541 (2012).

175. See Jeff Greenfield, Why We Need Those 'Anti-Democratic' Superdelagates, PoLiTiCo MAG. (May28, 2016), http://www.politico.com/magazine/story/2016/05/why-we-need-those-antidemocratic-superdelegates-213921 [https://perma.cc/5DYC-2KMM] (arguing superdelagates protect people and parties from bad candidates through their autonomy).

176. Williams, supra note 174, at 1559. 
no real judgment ${ }^{177}$ ). Indeed, we refer to electors who do think for themselves as rogues, though, fortunately, none has been truly consequential in choosing a President. That being said, if Donald Trump does win the election, it is entirely possible that some people will entreat the electors to exercise independent judgment and prevent him from taking office. ${ }^{178}$

The great alternative to direct election, of course, is parliamentary designation, in which the "bearer of supreme power" is always vulnerable to the parliamentary majority. ${ }^{179}$ Political parties can claim "mandates," but in a properly functioning parliamentary system, prime ministers cannot claim personal mandates that override the wishes of their parties or coalitions that placed them in power. ${ }^{180}$ But, of course, the United States, unlike most developed countries in the world today, has resolutely rejected parliamentarianism in favor of a byzantine system of separation of powers that explains the phenomenon of the 2016 election season. At the very least, this is a subject worth discussing in the constitutional convention that I continue to hope we have. Indeed, it would be a worthy topic should the voters of New York exercise their constitutionallygranted powers (under the New York State Constitution) to vote in 2017 to call a new convention to discuss amending that constitution. ${ }^{181}$ States have totally failed to serve as "little laboratories of experimentation" with regard to presenting alternatives to separation of powers, which is a real shame. ${ }^{182}$

In any event, the phenomenon of Donald Trump may be an illustration, dreadful but accurate, of the Weberian analysis. The sociopathic, narcissistic Trump is running a classically "Caesarist" campaign, relying on large rallies and whipping up crowds by the use of bombastic claims that ultimately rely on the

177. Michael G. Neubauer \& Joel Zeitlin, Outcomes of Presidential Elections and the House Size, 36 PS: PoL. SCI. \& PoL. 721, 722 (2003).

178. Indeed, following the election, I became one of those people! See Sanford Levinson, Jeremi Suri, \& Jeffrey Tulis, The Hail Mary Pass that Could Deny Donald Trump the Presidency: It's Up to You, Electors, NY DAILY NEws (Nov. 21, 2016 1:35 PM), http://www.nydailynews.com/ opinion/tulis-levinson-suri-hail-mary-defeat-donald-trump-article-1.2882315 [https://perma.cc/GE7N-TDUG] (calling on patriotic electors to unite in providing the House of Representatives with an alternative Republican that might be named to the presidency under the procedures set out by the Twelfth Amendment).

179. See Richard Albert, The Fusion of Presidentialism and Parliamentarianism, 57 AM. J. Comp. L. 531, 550-52 (2009) (discussing the implications of a vote of no confidence in parliamentary systems).

180. See generally Elijah Ben-Zion Kaminsky, On the Comparison of Presidential and Parliamentary Governments, 27 PRESIDENTIAL STUD. Q. 221, 221 (1997) (explicating the general argument that in a parliamentary system is more likely to lead to agreement about policies).

181. N.Y. CONST. art. XIX, § 2 .

182. The idea of having states act as laboratories for the federal government was coined in a famous dissent by Justice Brandeis: "[A] state may, if its citizens choose, serve as a laboratory; and try novel social and economic experiments without risk to the rest of the country." New State Ice Co. v. Liebmann, 285 U.S. 262, 311 (1932) (Brandeis, J., dissenting). 
premise that he alone can "make America great again." "183 It was George W. Bush who emphasized that he alone was "the decider." 184 Trump is building on that image of the presidency.

In all fairness, though, one should not assume that Weber's analysis kicks in only this year, without any such inklings prior to this dreadful political year (or to the Bush-Cheney regime). My colleague Jeff Tulis has written a classic book, The Rhetorical Presidency, ${ }^{185}$ that illuminates the differences between what might be called "classical" and "contemporary" conceptions of the presidency. ${ }^{186}$ Tulis emphasizes the break, which he identifies particularly with Woodrow Wilson, with a relatively modest conception of the presidency. ${ }^{187}$ Consider for starters that prior to the twentieth century, candidates really did not engage in personal campaigns; that was viewed as beneath the dignity of the office. ${ }^{188}$ Moreover, presidents sent written messages to Congress on the state of the Union rather than command a nation-wide audience to watch them deliver an address in person before a (usually) respectful Congress. ${ }^{189}$ President Wilson, who (justifiably) disdained much about the U.S. Constitution, envisioned himself as a prime minister charged with truly "leading" the nation. ${ }^{190}$ One might, of course, also pay attention to his predecessor Teddy Roosevelt and his conception of the presidency as offering a "bully pulpit." ${ }^{191}$ Both, perhaps, traced their conceptions of presidential authority back to Andrew Jackson's notion that he was a "tribune of the people," by virtue of what had become de-facto direct election. ${ }^{192}$ Perhaps not coincidentally, Jackson's opponents considered him an utter demagogue. ${ }^{193}$ His

183. See generally Tom Engelhardt, What Trump Really Means When He Says He'll Make America Great Again, THE NATION (Apr. 26,2016), https://www.thenation.com/article/what-trumpreally-means-when-he-says-hell-make-america-great-again/ [https://perma.cc/NXL4-RFYT] (reinforcing "make America great again" as the backbone of Trump's campaign and that Trump has said he alone can accomplish this).

184. Ed Henry \& Barbara Starr, Bush: "I'm the Decider" on Rumsfeld, CNN (Apr. 18, 2006, 10:30 PM), http://www.cnn.com/2006/POLITICS/04/18/rumsfeld/ [https://perma.cc/FLT3-WC5J].

185. JefFrey K. Tulis, The Rhetorical Presidency (1987).

186. See generally id.

187. David A. Crocket, George W. Bush and the Unrhetorical Rhetorical Presidency, 6 RHETORIC AND PuB. AfF. 465, 468-69 (2003).

188. But see Johnny Goodtimes, A Brief History of Campaign Mudslinging, from 1796 to Today, PhiladelPhia (Oct. 24, 2012, 9:07 AM), http://www.phillymag.com/news/2012/10/24/ presidential-campaign-dirty-politics-mudslinging/[https://perma.cc/LB57-B2PQ] (giving anecdotal examples of early personal attacks on presidential candidates, like Thomas Jefferson).

189. Ryan Lee Teten, Evolutionary Rhetorical Presidency: Tracing the Changes in Presidential AdDRESS AND Power 16 (2011).

190. See Crocket, supra note 187 , at 467.

191. See David Greenberg, Beyond the Bully Pulpit, 35 WILSON Q. 22, 25 (1976).

192. Donald O. Dewey, Madison's Response to Jackson's Foes, 20 TenN. Hist. Q. 167, 167 (1961).

193. Robert Whaples, Were Andrew Jackson's Policies “Good for the Economy”?, 18 INDEP. REV. 545, 545 (2014). 
predecessor, John Quincy Adams, a Harvard overseer, refused to support awarding Jackson an honorary degree, writing in his diary that the University was placing its "highest literary honors upon a barbarian who could not write a sentence of grammar and could hardly spell his own name." ${ }^{194}$ American Indians in particular might offer yet other reasons for considering Jackson a barbarian. The point is that even by 1828 the Publian assurances set out in The Federalist, that the President would always be a person of unusually sterling character and civic virtue, lost their persuasiveness. ${ }^{195}$

Modern communications technology, something you are far more familiar with than I, offers new possibilities to would-be demagogues. Although Calvin Coolidge, perhaps surprisingly, was the first President to make use of radio, ${ }^{196}$ it was of course FDR, with his fireside chats, who perfected that medium. ${ }^{197}$ And then there came television, and now we have, especially for Trump, Twitter. ${ }^{198}$

One might argue that the great quantum jump toward a more Caesarist conception of the presidency was the Kennedy election of 1960, when television really became important. ${ }^{199}$ An attractive young senator with precious little accomplishment to his name, but lots of "charisma,"-a Weberian word that first made its entrance into common punditry-made it to the top of the electoral greasy pole (with due help from his family fortune and the support of Chicago Mayor Richard J. Daley). ${ }^{200} \mathrm{He}$ and his wife charmed the public, and his assassination made many feel that we had lost a truly incomparable leader. ${ }^{201}$ And, of course, there was the psycho-drama of the Cuban Missile Crisis, where Kennedy simply ignored existing political structures in favor of the Executive Committee of the National Security Council (ExComm) and, ultimately, made the decision on his own to risk World War III by ordering a

194. Edward Pessen, Jacksonian America: Society, Personality, and Politics 180 (1985).

195. See The Federalist No. 68, at 414 (Alexander Hamilton) (Clinton Rossiter ed., 1961).

196. The Learning Network, Calvin Coolidge Delivers First Presidential Address on Radio, N.Y. Times (Dec. 6, 2011, 4:02 AM), http://learning.blogs.nytimes.com/2011/12/06/dec-6-1923calvin-coolidge-delivers-first-presidential-address-on-radio/ [https://perma.cc/3RYD-NKEL].

197. Id.

198. See Michael Barbaro, How Donald Trump Uses Twitter (Hint: Impulsively), N.Y. TIMES (Oct. 5, 2015), http://www.nytimes.com/2015/10/06/us/politics/how-donald-trump-uses-twitter.html [https://perma.cc/V76T-UPVS].

199. Don Gonyea, How JFK Fathered the Modern Presidential Campaign, NAT'LPUB. RADIO (Nov. 16, 2013, 7:30 AM), http://www.npr.org/2013/11/16/245550528/jfk-wrote-the-book-onmodern-presidential-campaigns [https://perma.cc/VH9K-GCZD].

200. Judy Keen, Chicago Ties Cast Shadow on 1960 Presidential Win, USA TODAY (Sept. 26, 2010, 10:30 PM), http://usatoday30.usatoday.com/news/washington/2010-09-26-jfk-chicagopolitics_N.htm [https://perma.cc/5KNZ-EGAN].

201. JFK Assassination: The World Mourns, CBS News (Nov. 23, 2013, 8:15 PM), http://www.cbsnews.com/news/jfk-assassination-the-world-mourns/ [https://perma.cc/5WC6292G]. 
"quarantine" of Cuba that fortunately worked. ${ }^{202}$

Skip forward to Ronald Reagan, who honed all of his professional skills to likewise charm the public (and, in fairness, he had demonstrated a competence for politics in governing California for eight years ${ }^{203}$ even if one was, like me, appalled by his political views). In any event, we seem more and more to look to presidents for "visionary leadership," not to mention largely fictive twenty-point programs that are presented as the cures for whatever ail us. As an avid supporter of Barack Obama in 2008 (against Hillary Clinton, of course), I think it is appropriate to note the Caesarist aspects of his own remarkable campaign, including the reliance on mass rallies and vague promises. ${ }^{204}$ Obama never once suggested that only he could guide us out of the political wilderness, but it was certainly the case that many of his supporters viewed him, in Maureen Dowd's snarky language, as "the One" whose unique abilities and "audacity" would lead us out of the wilderness. ${ }^{205}$ Not surprisingly, he disappointed such hopes, but that is another matter.

Republicans, of course, believe that Obama is increasingly governing in a Caesarist fashion. Obama has engaged in a variety of unilateral decisions, and some Republican judges agree (including, presumably, the four conservative Republicans who inhabit the current Supreme Court) ${ }^{206}$ I disagree with some of the claims to unilateral military authority that Obama has made,${ }^{207}$ even if they rest on, shall we say, generous readings of congressional delegations of power to the President. Perhaps his most dramatic exercise of unilateralism was his exchange of prisoners with the Taliban in defiance of a clear congressional directive that Congress be given thirty-days notice. ${ }^{208}$ One can readily agree with

202. The Cuban Missile Crisis, October 1962, OfF. Historian, https://history.state.gov/ milestones/1961-1968/cuban-missile-crisis [https://perma.cc/BUT7-3NRA] (last visited Nov. 12, 2016).

203. Ronald Reagan, HistORY.COM, http:/www.history.com/topics/us-presidents/ronaldreagan [https://perma.cc/ZW2E-EUVG] (last visited Nov. 12, 2016).

204. Fred Lucas, How Do Trump Crowd Sizes Really Compare to Obama's 2008 Crowds?, The Blaze (Mar. 14, 2016, 4:32 PM), http://www.theblaze.com/stories/2016/03/14/how-do-trumpcrowd-sizes-really-compare-to-obamas-2008-crowds/ [https://perma.cc/94XB-8PE4].

205. Maureen Dowd, A Storyteller Loses the Story Line, N.Y. Times (June 1, 2010), http://www.nytimes.com/2010/06/02/opinion/02dowd.html [https://perma.cc/M9KS-EYWL].

206. See, e.g., Richard Wolf et al., Federal Judge Strikes Down Obamacare Payments, USA TODAY (May 12, 2016, 6:02 PM), http://www.usatoday.com/story/news/politics/2016/05/12/ federal-court-obamacare-president-obama-republicans/84281474/[https://perma.cc/H4FX-MTRB]; Adam Liptak \& Michael D. Shear, Supreme Court Tie Blocks Obama Immigration Plan, N.Y. TiMEs (June 23, 2016), http://www.nytimes.com/2016/06/24/us/supreme-court-immigration-obamadapa.html [https://perma.cc/Y7LC-FJH2].

207. See Conor Friedersdorf, The Perils of Obama 's Latest Undeclared War, ATLANTIC (Nov. 2, 2015), http://www.theatlantic.com/politics/archive/2015/11/the-perils-of-president-obamaslatest-undeclared-war/413566/ [https://perma.cc/5KNC-B78P].

208. Jeremy Diamond, House Report Accuses Obama of Violating Law in Bergdahl Exchange, CNN (Dec. 10, 2015, 12:11 PM), http://www.cnn.com/2015/12/09/politics/taliban-5-bowe- 
his motives and still be a bit perturbed by his extravagant reading of his powers as Commander-in-Chief. ${ }^{209}$

It is certainly the case that both Democratic and Republican presidents have been extending their powers in reaction to the breakdown of Congress as a truly functioning institution. ${ }^{210}$ Caesarists' power, after all, is not necessary seized. It is often delegated by supine legislatures either caught up in party loyalty or a simple reluctance to engage in the hard tasks of governance (and the necessity of spending an inordinate amount of time raising money in a thoroughly corrupting system of campaign finance). ${ }^{211}$

What Trump wants is exactly what Weber predicted, an "acclamation" by scared masses who basically license him to do, quite literally, whatever he wishes to meet the problems he identifies. ${ }^{212}$ To believe, as do some of those "supporting" him without "endorsing" him (think, e.g., of Mitch McConnell), ${ }^{213}$ that he is capable of being internally constrained by the notion of legal obligation or duties is sheer fantasy. Sociopathic narcissists recognize no such internal obligations. They are the epitome of Holmesian "bad men," who calculate everything in terms of personal profit and loss. ${ }^{214}$

So we should at least consider the frightening possibility that Weber was correct almost a century ago in suggesting that Trumpism may be a dangerous virus located in the DNA of the American constitutional order. ${ }^{215} \mathrm{We}$ have seen the valorization of presidents as maximum leaders with grandiose visions, which they have "mandates" to implement, whatever it takes. ${ }^{216}$ No serious political

bergdahl-congress-report/ [https://perma.cc/844B-S2HZ].

209. For an example of the right-wing critique of Obama's actions, see Elizabeth Slattery \& Andrew Kloster, An Executive Unbound: The Obama Administration's Unilateral Actions, HERITAGEFound. (Feb. 12, 2014), http://www.heritage.org/research/reports/2014/02/an-executiveunbound-the-obama-administrations-unilateral-actions [https://perma.cc/NQL8-ZSDL].

210. Andrew Prokop, How Barack Obama Is Expanding Presidential Power-and What It Means for the Future, Vox (Sept. 9, 2014), http://www.vox.com/2014/9/9/5964421/obama-lawsuitrepublicans-abuse-of-power [https://perma.cc/EU3C-S8DC].

211. Guillermo O’Donnell, Delegative Democracy, 5 J.Democracy 55, 62 (1994) (explaining how delegative democracy has been analyzed under Caesarism).

212. Matthew MacWilliams, The One Weird Trait That Predicts Whether You're a Trump Supporter, Politico (Jan. 17, 2016), http://www.politico.com/magazine/story/2016/01/donaldtrump-2016-authoritarian-213533 [https://perma.cc/VBM7-9UYZ].

213. Andrew Rudalevige, No, White House Lawyers Would Not Prevent a President Trump from Overstepping His Constitutional Bounds, WASH. Post (June 14, 2016), https://www. washingtonpost.com/news/monkey-cage/wp/2016/06/14/no-white-house-lawyers-would-notprevent-a-president-trump-from-overstepping-his-constitutional-bounds/ [https://perma.cc/6YKSPKNN].

214. David Luban, The Bad Man and the Good Lawyer: A Centennial Essay on Holmes's "The Path of the Law," 72 N.Y.U. L. REV. 1547, 1574 (1997).

215. See generally MAX Weber, Politics as a Vocation, in From MaX WeBer: Essays IN Sociology 77 (H.H. Gerth \& C. Wright Mills trans., 1946).

216. Huma Khan, In First 100 Days, Obama Flips Bush Admin's Policies, ABC News (Apr. 
system should have to contemplate the possibility of being "governed" by a narcissistic sociopath.

These are truly dark times, though for reasons very different from those suggested by Donald Trump. My obsessive fear is that, when ${ }^{217}$ Hillary is elected, we will collectively congratulate ourselves for dodging a potentially fatal bullet and return to our blithe confidence. In Gerald Ford's reassuring words, "our long national nightmare is over" because "[o]ur Constitution works." ${ }^{218}$ I wish it were that easy. You are well aware of the important book published a few years ago by Eric Posner and Adrian Vermeule, The Executive Unbound: After the Madisonian Republic. ${ }^{219}$ It is notable, in my opinion, for its almost exuberant embrace of much of the jurisprudential approach of Carl Schmitt and his analysis of developments in Germany during the Weimar era, such as, the rise of the modern administrative state. The central point-which is true as well of a forthcoming book on the administrative state by Vermeule ${ }^{220}$ - is that, generally, the central characteristic of the modern state is the amount of discretion it lodges in the executive branch. ${ }^{221}$ And, to the extent one accepts some of the more extravagant theories of the "unitary executive," it is the President who ultimately enjoys a sufficient degree of discretionary authority. This is based either on readings of the Constitution or on broad statutes passed by Congress delegating power to the Executive, which justifies the assertion that the U.S. has its own form of "constitutional dictatorship," 222 especially if we elect a person who lacks a genuine internal compass. And, of course, the President gets to pick his own lawyers, the most important of whom are in the White House or the Office of Legal Counsel. ${ }^{223}$ George W. Bush found John Yoo and now-judge Jay Bybee. ${ }^{224}$ I have no doubt that a President Trump, empowered by the Constitution to nominate judges (who would be confirmed by a morally-bankrupt Republican Party who would prattle about their duty to follow the wishes of the public that elected Trump, which is how they have justified their spinelessness in endorsing

29, 2009) (noting how supporters celebrate Obama's executive orders), http://abcnews.go.com/ Politics/Obama100days/story?id=7042171\&page=1 [https://perma.cc/JK95-NSYL].

217. I clearly should have written "If"!

218. Gerald Ford, President, Gerald Ford Presidential Inauguration, History Place (Aug. 9, 1974), http://www.historyplace.com/speeches/ford-sworn.htm [https://perma.cc/9AC5-UQGH].

219. Eric A. Posner \& Adrian Vermeule, The Executive Unbound: After the MADISONIAN REPUBLIC (2011).

220. Adrian Vermeule, LAW's ABnEgation (forthcoming 2016).

221. See, e.g., Handbook of European Politics 195-96 (Knud Erik Jørgansen et al. eds., 2006) (discussing how conceptualizations of European Union members are increasingly defined by executive politics - particularly with respect to administrative delegation).

222. See Jack M. Balkin and Sanford Levinson, Constitutional Dictatorship: Its Dangers and Its Design, 94 Minn. L. ReV. 1789 (2010).

223. Rudalevige, supra note 213.

224. Randy James, Jay Bybee: The Man Behind Waterboarding, Time (Apr. 28, 2009), http://content.time.com/time/nation/article/0,8599,1894309,00.html [https://perma.cc/B2LZ$3 \mathrm{ECN}]$. 
Trump as their candidate), would find his share of ambitious lawyers, some educated, no doubt, at Harvard or Yale (think of the egregious Kris Kobach, the architect of the anti-immigrant laws that plague our country ${ }^{225}$ ), who would happily construe the extant legal materials to allow Trump to do just about whatever he wanted (remember, incidentally, the pardon power, the great wildcard in the American constitutional system that allows a President to offer a get-out-of-jail free card to whomever he or she wishes ${ }^{226}$ ). All of this is simply to suggest that those who place their faith in the Madisonian system of checks and balances to save us from the ravages of a sociopathic narcissist are deluding themselves. This is true at the empirical level, even if one shares their belief in Madisonianism. But James Madison has truly, and irrevocably, left the building.

This is a bit longer than my other letters, but, then, much has happened since November. I look forward to your own take on this time of our profound discontent.

Sandy

August 7, 2016

Dear Sandy:

I do not believe that Donald Trump's rise changes the analysis of constitutional dysfunction. To the contrary, it fits perfectly into the arguments I have been making. Trump's rise was not caused by a defective Constitution, but it is a response-however mistaken-to an increasingly undemocratic and unrepublican political system. (Indeed, Trump's rhetoric plays on fears that the system is rigged against ordinary people.) At the same time, your discussion of the threats posed by Trump's candidacy highlights some of the tensions implicit in your program of constitutional reform.

\section{WAS TRUMP EMPOWERED BY THE HARD-WIRED CONSTITUTION OR BY THE CONSTITUTIONAL ORDER?}

To what extent is Donald Trump's rise due to dysfunctional features of the Constitution? Recall the distinction I made in my first letter to you, between the "hard-wired Constitution" and the constitutional order-the entire set of rules,

225. Heather Digby Parton, The Kris Kobach Factor: Why You Must Get to Know Kansas' Radical Secretary of State, SALON (July 14, 2016, 8:00 AM), http://www.salon.com/2016/ 07/14/the_kris_kobach_factor_why_you_must_get_to_know_kansas_radical_secretary_of_state/ [https://perma.cc/7DAZ-FVAV].

226. Pardon Information and Instructions, U.S. DeP'T OF Just., https://www.justice.gov/ pardon/pardon-information-and-instructions [https://perma.cc/U3XA-AWXC] (last visited Nov. 12, 2016). 
doctrines, and practices that structure political decision making in the United States. Your argument focuses on altering the hard-wired Constitution through amendments or a new constitutional convention. By contrast, I argue that constitutional reform should focus on features of the constitutional order.

The best explanations for Trump's rise concern our current constitutional order, but they have little to do with the hard-wired Constitution. We might divide them into three categories. The first concerns the structure of contemporary media. ${ }^{227}$ The second concerns the structure of the party system. ${ }^{228}$ The third concerns where we are in political time - the decline of the conservative Reagan coalition and regime, and the gradual emergence of a new coalition and regime that will probably (but not necessarily) be dominated by the Democratic Party. ${ }^{229}$

\section{A. The Structure of Mass Media}

Over the past several decades, conservatives, frustrated with what they regard as liberal bias in media and the academy, have developed a separate set of conservative media, think tanks, and educational institutions. Coupled with the rise of cable news, the Internet, and geographical self-sorting, these institutions have created a conservative echo chamber. ${ }^{230}$ They have encouraged motivated reasoning, and helped to insulate conservatives from facts, opinions, and interpretations of facts contrary to their ideology and beliefs. ${ }^{231}$ These conditions primed Republican primary voters for takeover by a demagogue like Trump.

Although Trump appears to be a buffoon, he is actually extremely skilled at media manipulation, not only of conservative media, but of media in general. ${ }^{232}$ Trump knows how to use social media to speak directly to his followers, maintain audience attention, make hit-and-run attacks on his political adversaries, and continually change the subject when faced with the consequences of his previous controversial statements and actions. ${ }^{233}$

Advertiser-driven media depend on ratings and clicks; they need to create and extend controversies in order to compete for increasingly scarce audience

227. See infra Part I.A.

228. See infra Part I.B.

229. See infra Part I.C.

230. See Conor Friedersdorf, How Conservative Media Lost to the MSM and Failed the Rank and File, Atlantic (Nov. 7, 2012), http://www.theatlantic.com/politics/archive/2012/11/howconservative-media-lost-to-the-msm-and-failed-the-rank-and-file/264855/ [https://perma.cc/L9BTVXTX].

231. Id.

232. Nate Silver, How Donald Trump Hacked the Media, FiveTHiRTYEIGHT (Mar. 30, 2016), http://fivethirtyeight.com/features/how-donald-trump-hacked-the-media/[https://perma.cc/AY87EHXU]; Ben Shapiro, The Utter Media Brilliance of Donald Trump, DAILY WIRE (May 19, 2016), http://www.dailywire.com/news/5864/utter-media-brilliance-donald-trump-ben-shapiro [https://perma.cc/446A-CT59].

233. Shapiro, supra note 232. 
attention. Recognizing this, Trump managed to obtain disproportionate amounts of free media time during the primary season by creating a stream of entertaining and shocking controversies. ${ }^{234}$ In the early days of his candidacy, for example, cable news channels carried substantial portions of his political rallies, vaulting him into first place in the Republican primaries. ${ }^{235}$ All other things being equal, voters are likely to support candidates who are most salient to them, even when they are controversial; indeed, the more controversial a candidate, the more free airtime he or she may receive. ${ }^{236}$ Trump's media savvy allowed him to leap past a crowded field and win the Republican nomination among the highly partisan and ideological Republican base.

\section{B. The Party System}

Contemporary American politics is strongly polarized and features conflict extension. Polarization means that the parties are far apart on issues with very little middle ground for compromise. Conflict extension means that the parties are polarized on more and more issues, so that if you know a politician's views on issue $A$, you also know their views on issue $B$, even if the two issues are unrelated. ${ }^{237}$

Moreover, political polarization is asymmetrical. Although the Democratic Party has moved to the left in the past two decades, the Republican Party has moved much farther to the right, and its political base has become increasingly radical. ${ }^{238}$

Increasing economic inequality tends to exacerbate political polarization. ${ }^{239}$ To the extent that polarization has prevented reforms that would lessen economic

234. Nick Gass, Study: Trump Boosted, Hillary Hurt by Primary Media Coverage, Politico (June 14, 2016, 6:51 AM), http://www.politico.com/story/2016/06/media-study-trump-helpedclinton-hurt-224300 [https://perma.cc/KK7S-CG8Q].

235. Michael M. Grynbaum, CNN's Coverage of Trump Was Biased, Presidential Candidates' Aides Say, N.Y.TIMES (Dec. 1, 2016), http:/www.nytimes.com/2016/12/01/business/media/trumpcnns-coverage-biased-presidential-candidates-aides-say.html?_r=0 [https://perma.cc/B6NR-96BN] (describing CNN's coverage of Trump rallies).

236. See John Wihbey \& Denise Marie-Ordway, Presidential Debates and their Effects: An Updated Research Roundup, JOURNALIST'S RESOURCE http://journalistsresource.org/studies/ politics/elections/presidential-debates-effects-research-roundup [https://perma.cc/2HER-7CH9] (last updated Sept. 20, 2016) (discussing recent research regarding voter salience and support of presidential candidates).

237. Geffrey C. Layman \& Thomas M. Carsey, Party Polarization and "Conflict Extension" in the American Electorate, 46 AM. J. PoL. SCI. 786, 789 (2002).

238. Thomas E. Mann \& Norman J. Ornstein, It's Even Worse than It Looks: How the American Constitutional System Collided with the New Politics of Extremism 51-58 (2012) (describing asymmetric polarization).

239. Nolan McCarty, Keith T. Poole, and Howard Rosenthal, Polarized America: The Dance of Ideology and Unequal Riches 3-4 (2d ed. 2016) (explaining how political polarization and economic inequality lead to and amplify each other). 
inequality, it creates a vicious cycle. ${ }^{240}$ This creates fertile ground for a politician like Trump.

\section{Political Time}

Globalization and the Great Recession exacerbated growing fractures within the Reagan coalition and the Republican Party. Thus, even as Republicans were increasingly polarized in opposition to liberals and Democrats, they began to fight among themselves; and different parts of the Republican coalition were increasingly at odds with each other. Although many Republican political elites, donors, and intellectuals continue to press for smaller government, entitlement reform, lower taxes for the wealthy, free trade, and immigration reform, the Republican base has developed different priorities. These include opposition to free trade and immigration, and support for social insurance programs like Medicare and Social Security, which benefit white working class and middle class voters.

Trump has seized on the fractures between Republican elites and the Republican base, catering to the base's values and their sense that they have repeatedly been betrayed by Republican elites and by politicians who give lip service to their values but pursue a very different agenda once in power.

It is no accident that Trump's political rise occurs as the Reagan regime that dominated American politics since 1980 is breaking down, a point I alluded to in my first letter to you. The demographic coalition that sustained the Reagan regime has been in decline for some time and is on the verge of becoming a minority. The successful coalition that Reagan forged is gradually being supplanted by a new coalition of women, minorities, millennials, professionals and college-educated people. This coalition swept Barack Obama into office and increasingly supports the Democratic Party. ${ }^{241}$

The long term shift in power between these respective coalitions was already obvious in the 2012 election; it led to the famous "autopsy" report that argued for Republicans to expand their base by supporting comprehensive immigration reform and courting the Latino vote. ${ }^{242}$ In a now famous quote, a Republican operative told National Journal's Ronald Brownstein that demographic changes had eclipsed traditional Republican strategies: "This is the last time anyone will try to do this"- that is, rely almost exclusively on white voters and appeals to their anxieties to win a presidential election. ${ }^{243}$

Trump, sensing an opportunity, has decided to ignore this advice, double

240. Id. at 3-4.

241. See Ronald Brownstein, The Hidden History of the American Electorate (II), NAT'L J. (Aug. 24, 2012), https://www.yahoo.com/news/hidden-history-american-electorate-ii-175214333. html [https://perma.cc/DYR8-2M6N] (describing Obama's “coalition of the ascendant").

242. Republican Nat. Comm., Growth and Opportunity Project 15 (2012).

243. Ronald Brownstein, The New Political Math, Real Clear Politics (Aug. 24, 2012), http://www.realclearpolitics.com/2012/08/23/the_new_political_math_288266.html [https://perma.cc/Y977-V8DB]. 
down and attempt an overtly white nationalist campaign to garner an even larger percentage of white voters than Ronald Reagan, the Bushes, or Mitt Romney. He is making a calculated bet that the Reagan coalition can be revived one more time; or, more likely, that it can be restructured as a coalition organized around the South, the Mountain West, and blue collar, non-college educated whites, especially in the Rust Belt.

As I explained in The Last Days of Disco, the decline of the Republican Regime and the demographic changes in the American voting population have caused the Republican Party to experience what we might call either a civil war or a nervous breakdown. ${ }^{244}$ It is precisely these circumstances that allow a demagogue like Trump to step forward, promise that he alone can make things right, and restore the former glory and status of the now decrepit regime and its constituents. Accordingly, Trump has based his campaign on a politics of fear and status resentment, aiming his message primarily at conservative white voters, especially those who lack a college education. Trump stokes their fears about invasion from Muslim terrorists and Mexican immigrants. ${ }^{245} \mathrm{He}$ appeals to their anxieties about becoming a powerless minority group and suffering a decline in their previously superior social status as whites. Trump is hardly the first Republican candidate to engage in a racially tinged status politics directed at conservative whites. ${ }^{246}$ But because the percentage of white voters in the population is shrinking ${ }^{247}$ he has been far blunter and more overt in his appeals. He needs the votes of every white voter he can muster, and therefore he is shouting what previous candidates used to whisper.

Obviously, one can quibble about the details of these explanations for Trump's rise. But the more important point is that none of these phenomena are centrally caused by the hard-wired Constitution. To be sure, the hard-wired Constitution shapes the conditions in which parties form and party coalitions rise and fall. And because of the Electoral College, it also shapes how presidential campaigns are run. But far more important influences are structures of party competition that are not required by the hard-wired Constitution (which does not

244. Balkin, supra note 16 , at 1170.

245. Patrick Healy \& Michael Barbaro, Donald Trump Calls for Barring Muslims from Entering U.S., N.Y.TIMES (Dec. 7, 2015), http://www.nytimes.com/politics/first-draft/2015/12/07/ donald-trump-calls-for-banning-muslims-from-entering-u-s/ [https://perma.cc/DW63-545W]; Theofore Schleifer, Trump: Mexican 'Rapists' Coming Now, Middle East 'Terrorists' Coming Soon, CNN (June 25, 2015, 8:47 PM), http://www.cnn.com/2015/06/25/politics/donald-trumpmexicans-terrorists-immigration-2016/index.html [https://perma.cc/NN8X-ZGDR].

246. See, e.g., Mary D. Edsall and Thomas Byrne Edsall, Chain Reaction: The Impact of Race, Rights, and Taxes on American Politics (1992); Theodore R. Johnson \& Leah Wright Rigueur, Race-Baiting for the Presidency, AtLANTIC (Nov. 18, 2015), http://www. theatlantic.com/politics/archive/2015/11/racial-divisiveness-as-a-campaign-strategy/416412/ [https://perma.cc/T3EL-JPJ5].

247. Asma Khalid, Republicans' White Working-Class Trap: A Growing Reliance, NPR (Jan. 18, 2016), http://www.npr.org/2016/01/18/462027861/republicans-white-working-class-trap-agrowing-reliance [https://perma.cc/3GU5-QENN]. 
mention parties at all), as well as features of mass media that have been far more driven by technology and economics than by constitutional design.

Both you and I agree, Sandy, that structural features of our constitutional system shape presidential politics in the United States. But in explaining Trump's rise, the most important of these structural features are not hard-wired provisions of the Constitution. The most important features are part of the constitutional order; they result from statutes, administrative regulations, political conventions, the organization of political parties, and court-created constitutional doctrines that could also be modified by courts. Above all, Trump's rise is the result of economic, social, and technological factors that sit atop the incentives created by the hard-wired Constitution. If we want to prevent future demagogues like Trump, the best remedy is not an Article $\mathrm{V}$ amendment, much less a constitutional convention.

\section{PResidential CAESARism}

Although Trump's rise in American politics is consistent with much of the previous analysis in our exchange, it also highlights tensions in your arguments for constitutional reform.

In my previous letters I pointed out that your program of constitutional reform seeks two different things. First, you want to make the constitutional system more democratic with a small "d." You want to eliminate unnecessary veto points and blockages in the system, and make it easier for Americans to pass laws that they need. You also want to enable ordinary individuals to circumvent elite political institutions through populist devices like the referendum and the initiative, and through constitutional conventions, which, you hope, could be staffed by ordinary individuals.

Second, you want sensible legislative solutions and progressive outcomes, with appropriate protection for civil rights and civil liberties.

In my first letter I pointed out that these two goals are not the same and may sometimes conflict. Trump's rise as a national political candidate shows us why. On the one hand, he promises to break through existing political obstacles, reenergize government, and get things done. On the other, he promises a frightening politics that bears almost no relationship to sound public policy and threatens civil rights and civil liberties.

You advert to the problem in your discussion of Max Weber, and his suggestion that "all systems of 'direct election by the people of the bearer of supreme power' have within them an impulse . . toward Caesarism." ${ }^{248}$ You argue that Weber's logic applies increasingly to the United States.

There is a little bit of irony in your invocation of Weber. You have argued that the central problem with our system of government is that it is insufficiently parliamentary and insufficiently responsive to popular will. You want to break down the barriers that constrain majorities. Yet the system that you want to move

248. Max Weber, Parliament and Government in Germany Under a New Political Order, in Weber: Political Writings 130, 221 (Peter Lassman \& Ronald Spiers eds., 1994). 
towards is the system that Weber thought contained the seeds of Caesarism!

Moreover, if your fear is demagogues and dictators, the last thing you should be pushing for are national referenda and initiatives. History has shown repeatedly that when dictators and demagogues seek to consolidate power, they turn to direct democracy to evade constitutional limitations and demonstrate that they enjoy the support of the people. ${ }^{249}$ One can easily imagine Donald Trump turning to direct democracy to circumvent a polarized Congress and justify one of his outrageous schemes.

I think that there is a better way to make your point. The framers of our Constitution created a system of checks and balances to prevent demagogues and dictators from seizing power, and from working their will if they gained power. These checks and balances also distinguish American democracy from a parliamentary system. You point out, however, that this system of checks and balances has gradually been undermined, especially in foreign affairs, but also through the expansion of the administrative state. (This is what you mean when you say that James Madison has left the building.) Moreover, because of partisan polarization and gridlock, presidents have increasingly turned to the administrative state to create the effective equivalent of presidential lawmaking. ${ }^{250}$ The worse Congressional gridlock becomes, the more presidents push the envelope of what they can do within the executive branch (including through waivers and agreements with individual states and localities). ${ }^{251}$ Doing an end-run around Congress infuriates the President's opponents in Congress even more. They refuse to cooperate, double down on their intransigence, and the cycle continues. To be sure, as you and I have argued in our work on constitutional dictatorship, there are limits to presidential unilateralism, especially in domestic affairs. ${ }^{252}$ But that does not keep frustrated presidents from testing those limits.

The result is a system that has many of the dangers of parliamentarianism with none of its benefits. Increasingly, Congress fails to be a serious partner in governing, while the President grows ever more powerful and ever more crucial to solve the nation's problems. Indeed, in the public's eyes, the President becomes virtually the sole cause of the country's successes and misfortunes. You and I have written about America's gradual movement toward a plebiscitary presidency, in which the President asserts that he or she can lead the country out

249. Margaret Thatcher, quoting Clement Atlee, famously called referendums "a device of dictators and demagogues." Ian Buruma, The Referendum Charade, THE STRATEGIST (Mar. 10, 2016), https://www.aspistrategist.org.au/the-referendum-charade/ [https://perma.cc/T7QZ-P599].

250. Gillian E. Metzger, Agencies, Polarization, and the States, 115 Colum. L. Rev. 1739, 1752-54 (2015); Balkin, supra note 16, at 1193-95.

251. Metzger, supra note 250, at 1752-54; Jessica Bulman-Pozen, Executive Federalism, 102 VA. L. Rev. 953 (2016); David J. Barron \& Todd D. Rakoff, In Defense of Big Waiver, 113 Colum. L. ReV. 265 (2013); Balkin, supra note 16, at 1193-95.

252. See Jack M. Balkin \& Sanford Levinson, Constitutional Dictatorship: Its Dangers and Its Design, 94 MinN. L. REV. 1789, 1829-30 (2010) ("Presidents exercise far less unilateral control in domestic politics.”). 
of its current problems and into a glorious future. ${ }^{253}$ In a plebiscitary presidency, media manipulation becomes increasingly important. Voters pay less attention to substantive issues (to the extent that they ever did) and more attention to personal charisma, emotional connection, and grand narratives about the country's direction. Plebiscitary presidencies also encourage unscrupulous candidates to engage in status politics, pitting social groups against each other and manipulating people's fears about potential loss of status. Because, at least in the short run, social status is a zero-sum good, status politics can make politics more emotional, volatile, and subject to motivated reasoning. Moreover, reforms to the system of presidential primaries adopted by both parties in the early 1970s have made presidential nominations depend much more on the vote of the most politically mobilized and ideological segments of the general public. ${ }^{254}$ Primary voters, especially ideologically extreme voters, anxious about their social status, and seeking reassurance and emotional uplift, may be the most vulnerable to the blandishments and manipulations of a demagogue like Trump.

People on both sides of the political divide understand the dangers, although they describe them in different ways. Recently, political conservatives, who had previously advocated for a powerful and "unitary" executive, have begun to express great discomfort with the administrative state. ${ }^{255}$ Part of this is due to the fact that conservatives fear that they will not control the executive branch very often in the near future. But part of it is also due to principled concerns about long-term threats to representative democracy and to the rule of law.

In the face of these criticisms, liberals should resist the temptation-almost automatic in today's polarized politics - to engage in reflexive defense of the status quo. Rather, they should take the critique of the administrative state seriously. In the face of Congressional obstruction, presidents may have expanded their lawmaking capacities within the administrative state for lack of any better alternatives. But doing so has generated a vicious cycle - the more presidents try to solve problems unilaterally, the more intransigent Congress becomes. ${ }^{256}$ And in the process, this strategy has distorted the system of checks and balances that guards against abuses by demagogues and would-be dictators. Liberals should be eager to find ways to remedy these distortions as we move to a less polarized

253. Id. at $1852-55$.

254. Raymond J. La Raja, Party Nominating Procedures and Recruitment-State and Local Level, in L. Sandy Maisel \& Jeffrey M. Berry, The OXFord Handbook of American Political PARTIES AND INTEREST GROUPS 165, 177 (2010) (noting that closed primaries tend to attract the most ideologically committed voters).

255. See, e.g., Charles J. Cooper, Confronting the Administrative State, 25 NAT'L AfFAIRS (2015), http://www.nationalaffairs.com/publications/detail/confronting-the-administrative-state [https://perma.cc/XH7A-C6TE]; Michael S. Greve, Yoo to Conservatives: Reverse Course, L. LiBERTY BLOG (Sept. 9, 2015), http://www.libertylawsite.org/2013/09/09/yoo-to-conservativesreverse-course/ [https://perma.cc/7LUA-XDPF]; John Yoo, A Thousand Little Tyrants-Obama's Problems Are a Chance to Rein in the Bureaucracy, NAT'L REV. (Sept. 16, 2013) https://www. nationalreview.com/nrd/articles/357088/thousand-little-tyrants [https://perma.cc/Y7NR-LNG9].

256. See Balkin, supra note 16, at 1193-95. 
politics - for they will not always be in control of the executive branch either.

Although we differ on the causes, you and I agree that our current political practices are unsustainable in the long run, and that they create two serious dangers. The first is that the country will be unable to deal effectively with the long term problems it faces and the various crises that may confront it from time to time.

The second problem is that if our system of governance is not reformed, it will increasingly fail to protect important civil rights and civil liberties. (In saying this, I do not pretend that it currently protects them adequately.) The dispute between us is not whether constitutional reform is necessary. It is about what kind of constitutional reform makes the most sense.

I believe that many of our current problems, but by no means all, will be ameliorated as we gradually transition from the decaying Reagan regime into a new regime, whether that new regime turns out to be dominated by Republicans or Democrats. Then we must begin the long, slow process of making our political system both more democratic and more republican.

Such a transition will be necessary for any kind of serious constitutional reform to occur. In fact, the kind of constitutional reforms you seek-Article V amendments or a new constitutional convention - are nonstarters in our currently polarized politics. In any case, my hope is that the transition to a new regime will offer possibilities for reform of the constitutional order that do not require Article $\mathrm{V}$ amendment or a new convention-although, as I noted previously, I am not opposed to either in principle.

An important part of the solution, therefore, is to maintain constitutional faith, and allow American politics time to transition, even as we continue to press for reforms. I advocate patience but not quiescence. We may not be able to do much in the short term to fix our broken politics - other than trying to hasten the transition through winning elections. But that is hardly a reason to refrain from pointing out the many flaws in our political system, and persuading people why we need to make changes. When reform finally becomes possible, we will need the best possible proposals for how to proceed.

Jack

November 26, 2016

Dear Jack,

So our epistolary exchange continues, unexpectedly, for a very simple reason. The barely imaginable in fact happened, and we now have an ignorant sociopath as presumptive president-elect ${ }^{257}$ (and, by the time this issue is actually published,

257. I use this rather awkward term because he does not truly become the "President-elect" until a majority of the various state electors vote for him on December 19. Until then, all we can 
probably as President of the United States). To paraphrase Abraham Lincoln, "we are now engaged in a great natural experiment to see if the vision of a Republican Form of Government enunciated in 1776 and then again in 1787 will endure," or if we are condemned to suffer the fate of most such experiments and decline into one or another form of authoritarian rule.

The primary constitutional problem presented by Donald Trump, I think we both agree, is that the American constitutional order, that blend of written institutional structures and unwritten conventions and political culture, is supposed to prevent the takeover of our political system by an unscrupulous demagogue without the slightest qualification to be President. They failed, largely, I believe, for the reasons you outline; Trump realized better than did any other candidate that "the traditional media" have become delegitimized by the rise of "social media" that privileges "truthiness" and, indeed, outright lies, over what used to be regarded as facts. Similarly, he recognized how the Republican Party had become vulnerable to a hostile takeover. I would, however, continue to assign the deficiencies of the 1787 Constitution at least a bit of causal influence in explaining the sheer level of rage at the breakdown of ordinary governance that presumably motivated some of the Trump voters to believe they had "nothing to lose" in rejecting what would almost undoubtedly have turned into four more years of the status quo given the continuation of divided and gridlocked national government. As I wrote above, I believe that the pleasure of a Clinton election, even if accompanied by a Democratic Senate (and thus the recapture of the Supreme Court) would have been succeeded quickly by depressed recognition that Paul Ryan and the "Freedom Caucus" would allow her no domestic victories and that she would, in 2020 , be the most vulnerable incumbent at least since Herbert Hoover in 1932. Now we might hope that that fate is assigned to Donald Trump!

But I worry about getting to 2020 . I do think that we are in the most serious existential internal crisis since 1860 . Significantly more Americans preferred Hillary Clinton than Donald Trump, but our completely anachronistic Electoral College tossed the election to the second-place finisher. No sane political system would adopt such a decision procedure today. The Electoral College, like the Senate, is a bizarre "affirmative action program" that overweighs the voting power of small states and the political power of those lucky residents of "battleground states." The states where most Americans live-think only of California, Texas, New York, and Illinois, received almost no visits or genuine consideration from the candidates. More to the point, most of those who opposed Donald Trump consider him an illegitimate president on both procedural and substantive grounds. As to the first, he ran the most completely dishonest campaign in American history. He is a congenital liar who was more than willing to repeat whatever he thought might gain him the votes of basically ignorant people who made no effort to check the accuracy of his statements or, even worse, simply didn't care that they were lies. When one adds to the elemental

say, as a technical matter, is that the odds are very much in his favor, as most people, of course, mistakenly thought was the case with Hillary Clinton on November 7, 2016. 
dishonesty of the campaign the systematic efforts to suppress the vote in such Republican bastions as Wisconsin and North Carolina, for starters, then one has additional reason to doubt the integrity of the overall process, even without taking into consideration the inanity of Electoral College. But there is also the fact that Donald Trump is totally without any of the intellectual skills or personal virtues that we look for in presidents. If he is to be obeyed and taken seriously as President, it is for the reason set out in King Lear: Even "a dog's obeyed in office., 258

All of this helps to explain why I, and many others, have joined, postelection, in pleading with Republican electors to save the republic by acting under the original vision of the Electoral College, i.e., to engage in what Publius in Federalist No. 1 called "reflection and choice" as to who should take the national helm rather than simply act like lemmings committed to a potentially suicidal choice for the nation. Although some, like my friend and sometime colleague Larry Lessig, have eloquently argued that Hillary Clinton should be selected, ${ }^{259}$ I think this is a political non-starter, in part because of the sentiment of one response that I received shortly after the publication, with two University of Texas colleagues, of an op-ed in the New York Daily News endorsing the proposition that electors should exercise their constitutional right (and duty) to engage in autonomous choice regarding who should be the next President of the United States. "They can try and steal it from President Elect Trump," wrote an angry respondent, "but if they do get ready for Martial Law under Obama because there are 70 million of us and we'll make the radical left wing riots currently underway look like a picnic. The Establishment lost this one, deal with it." ${ }^{260}$ What Democrats must realize is that salvation of the republic may rest on the willingness of sufficient Republican electors to identify a palatable alternative to Trump who can gain enough votes to deprive him of his electoral vote majority and throw the election into a Republican-dominated House of Representatives. Perhaps the writer quoted above would be equally hostile to that kind of deal, since it would, after all, send Donald Trump back to Fifth Avenue and Mar-aLago instead of to the Oval Office. Are there enough devoted Trumpistas, with guns, who will threaten significant civic disorder in such a case? The only plausible answer is "perhaps," which is not encouraging and may lead one to counsel simply accepting Trump's election.

In any event, I do believe that, at least psychologically, we are at the brink of civil war inasmuch as critical masses on both right and left basically look at their

258. See William ShakeSPeARe, King LeAR act 4, sc. 6 ("Thou hast seen a farmer's dog bark at a beggar? ... And the creature run from the cur? There thou mightst behold the great image of authority: a dog's obeyed in office.").

259. Lawrence Lessig, The Constitution Lets the Electoral College Choose the Winner: They Should Choose Clinton, WASH. Post (Nov. 24, 2016), https://www.washingtonpost. com/opinions/the-constitution-lets-the-electoral-college-choose-the-winner-they-should-chooseclinton/2016/11/24/0f431828-b0f7-11e6-8616-52b15787add0_story.html?utm_term=. 7ee03889a73b [https://perma.cc/T5MS-GMPD].

260. Email from D. J. Perez to Sanford Levinson (Nov. 21, 2016). 
fellow Americans as enemies who must be stopped at almost any cost. This, to put it mildly, is not ordinary politics. It represents the breakdown of a functioning political system that relies on a certain code of what might be described as a willingness to be a "good sport" after losing an election and saying, as did the fans first of the Brooklyn Dodgers and then the Chicago Cubs, "wait "til next year"- and "next year" finally came for both teams, of course. Is that a good enough reason to roll over and accept the verdict of the minority of the American voters who voted for the sociopath? It all depends on how dangerous one believes that Trump and his minions are, and I believe they are dangerous indeed.

How, if he becomes President, might the civil war begin, since there will certainly be no Fort Sumter to signal the beginning, and a California vote for secession apparently won't take place until 2019. I think the most likely beginning would be reminiscent of the violence in the streets of Boston over the rendition of fugitive slaves like Anthony Burns. ${ }^{261}$ After all, one should be clear that Burns violated the law by fleeing his confinement as a slave, and the august Supreme Court, in the worst single decision in our history upheld the Fugitive Slave Law of 1793 in Prigg v. Pennsylvania. ${ }^{262}$ Abraham Lincoln himself, the Great Emancipator, declared that Republicans had a duty to concede the constitutionality of the Fugitive Slave Law inasmuch as it was in effect part of the deal that had been made with the slaveowners in order to get the Constitution in the first place. ${ }^{263}$ Many Bostonians (and Wisconsites) disagreed and moved, in effect, to nullify the operation of federal law with regard to fugitive slaves. So do a fast forward to 2017, and imagine that peaceful families of undocumented aliens start being rounded up and sent to concentration camps prior to their deportation. Many of us, I hope, would see it as our duty to stand in solidarity with them and prevent the legal authorities from being able to carry out their own legal "duties." Federal authorities should become aware of the absolute contempt in which they are held by one group within the community even as, undoubtedly, there would also be many people cheering them on.

Perhaps this is all too melodramatic, even apocalyptic. President Obama himself has apparently reassured his own daughters that this, too, will pass, that America is too resilient to be permanently deflected from moving further along the arc of justice. ${ }^{264}$ I obviously hope he is right. Donald Trump, after all, seems primarily to be rapaciously devoted to amassing greater and greater wealth, and he clearly views the presidency as a path to enhanced fame and fortune. New American wars, and especially a world war, would not be conducive to his

261. See, e.g., Boston Combusts: The Fugitive Slave Case of Anthony Burns, HistoryNeT (Apr. 19, 2007), http://www.historynet.com/boston-combusts-the-fugitive-slave-case-of-anthonyburns.htm [https://perma.cc/TJ29-XS63].

262. 41 U.S. 539 (1842).

263. Fugitive Slave Act of 1850, Lincoln StUd. (Sept. 18, 2007), http://lincolnstudies. blogspot.com/2007/09/fugitive-slave-act-of-1850.html [https://perma.cc/WY2L-ATBP].

264. David Remnick, Obama Reckons with a Trump Presidency, New Yorker, (Nov. 28, 2016), http://www.newyorker.com/magazine/2016/11/28/obama-reckons-with-a-trump-presidency [https://perma.cc/4RTZ-4PJG]. 
financial gain. In the meantime, concerned Democrats must do everything they can to identify and work with those honorable Republicans who actually meant "never Trump." If there are only half a dozen in the Senate, then Trump's worst appointments (or at least those requiring Senate confirmation) can be blocked. Undoubtedly this will mean that Democrats themselves will have to acquiesce in some conservative programs they would ordinarily do everything in their power to oppose. That, for better or worse, is what serious compromise entails. The original Constitution came into being only because its proponents were willing to compromise with slaveowning states (thorough the three-fifths rule, most notably) and small states (through equal voting power in the Senate). One can make a serious argument that the Constitution wasn't worth it, especially since we live every single day today with the consequences of both of those compromises. But perhaps it was. There are times when pacts with the devil are necessary, as with the alliance with Josef Stalin against Adolf Hitler. Nothing that Al Qaeda could do so threatens the American fabric as does Donald Trump and the truly deplorable part of his base, even if we take necessary care to concede that they may represent only a relatively small subset of the larger number of people who voted for him in their understandable desire to remonstrate (a true euphemism) against elites of both parties that had almost willfully ignored their plight in the rush toward globalization. No doubt many of those who voted for the Nazis in 1933 also had "understandable reasons" to do so. It really didn't matter once they seized power through legal means.

Please persuade me that I'm wrong to be so anxious about our country and its future under a Trump presidency.

Your devoted friend,

Sandy

December 3, 2016

Dear Sandy:

We began this exchange over a year ago by asking whether American democracy has become dysfunctional. Along the way, we have debated what "dysfunction" means, and whether the causes of dysfunction lie in our Constitution or in other aspects of our political system. We have also debated whether the causes of dysfunction are "hard-wired"-requiring an Article V amendment or convention to repair-or whether the solutions lie in some combination of political reform, mobilization, perseverance and persistence.

The 2016 election has confirmed that American democracy is dysfunctional. But it has confirmed it in a most unexpected way. Both of us assumed that Hillary Clinton would win the presidency and that we would face four years of political gridlock and trench warfare. What has happened instead is that Americans have elected a demagogue to the presidency. 


\section{THE FRAGILITY OF REPUBLICS}

The Founders, steeped in the history of the rise and fall of republics, worried that something like this could and would come to pass. Republics, they believed, are delicately calibrated instruments of political power that require perpetual vigilance and civic virtue to maintain. ${ }^{265}$ Civic virtue means devotion to the public good and the ability and the willingness to sacrifice short-term political selfinterest for the greater good of the Res Publica-the public thing that simultaneously constitutes and motivates a well ordered state. ${ }^{266}$

The famous quip, attributed to Benjamin Franklin, that the Framers had founded "[a] republic, . . . if you can keep it," 267 adverted to the history of the rise and fall of republics, and the difficulty of maintaining them over long periods of time. Speaking at the conclusion of the 1787 Convention, Franklin predicted that the new government "is likely to be well administered for a course of years, and can only end in Despotism, as other forms have done before it, when the people shall become so corrupted as to need despotic Government, being incapable of any other."268

Why are republics difficult to keep? Republics are always subject to corruption: corruption of civic officials, who seek to promote their own interests and entrench themselves in power; and corruption of the citizens, who become cynical, internally divided, and lose faith in the idea of a common good and in the possibility of a common project of governance involving their fellow citizens. ${ }^{269}$

The corruption of republics involves more than dishonesty and selfishness. Above all, it involves a loss of faith - faith in the ability and the good will of leaders and public institutions, and faith in the good will of one's fellow citizens. Loss of faith and selfishness go together - the one exacerbates the other. In a republic sliding into corruption, citizens look around them and all they see are smug, dishonest elites, scheming politicians, condescending cosmopolitans and baskets of deplorables. Because the people have lost faith in public institutions, in their fellow citizens, in the possibility of working for common ends-indeed,

265. See Gordon S. Wood, The Creation of the American Republic, 1776-1787, at 68 (1969) (“A republic was a delicate polity precisely because it demanded an extraordinary moral character in the people.").

266. Thomas Paine, The Rights of Man: Being an Answer to Mr. Burke's Attack on the French Revolution (1791), in COLLECTED WRITINGS 565 (Eric Foner ed., 1995) ("RES-PuBLICA, the public affairs, or the public good; or literally translated, the public thing ... refer[s] to what ought to be the character and business of government.").

267. Walter IsaAcson, Benjamin Franklin: An American Life 459 (2003).

268. 2 The Records of the Federal Convention of 1787, at 641 (September 17, 1787) (Max Farrand ed., rev. ed. 1966).

269. See J.G.A. Pocock, The Machiavellian Moment: Florentine Political Thought and the AtLantic Republican Tradition 527 (1975) ("Virtue can develop only in time, but is always threatened with corruption by time."); WooD, supra note 265, at 105 ("Precisely because republics required civic virtue and disinterestedness among their citizens, they were very fragile polities, extremely liable to corruption."). 
in the very idea of achieving a common good-they become selfish, clannish, angry, suspicious, despairing and distrustful. Their attitudes and actions further corrode faith in public institutions and in the republic, and the cycle of corruption continues. ${ }^{270}$

In the traditional account, as republics decay into ever greater corruption, the public hungers for strong leadership to repair what has fallen into disrepair. Their desire to set things right encourages the rise of unscrupulous demagogues, who offer blandishments and lies; they promise that they will restore the republic's lost glory through the sheer force of their will. ${ }^{271}$

Demagogues do not usually sneak up unawares. Members of the public often know that demagogues are selfish, unethical, and unscrupulous, but they convince themselves that turning to such leaders is the only way to smash corrupt institutions and solve the country's problems. Once in power, however, demagogues become tyrants, bringing republican government to an end.

This is the traditional story of how republics decay and fall. The story was well known to the founders of our country. ${ }^{272}$ They hoped that they could create a new kind of republic that would resist the natural tendencies toward decay in all republics throughout history. The devices they hoped would prevent this fate included a large federal republic that would diffuse and temper factionalism, federalism, separation of powers, checks and balances, and institutions of civil society that would inculcate virtue in the citizenry and instill respect for education, learning, and accomplishment. ${ }^{273}$

How well does the traditional account of the decay of republics match our present situation? The resemblance is altogether frightening. Republican themes have been implicit in our entire exchange of letters about democracy and dysfunction. Government dysfunction has caused — and been caused by-political polarization, factionalism, the corruption of the political process, and the public's loss of faith in public institutions and in the public good. Decades of politicians

270. Philip Pettit, Republicanism: A Theory of Freedom And Government 210 (1997) (explaining that in the republican tradition corruption occurs when people "make their decisions by reference not to considerations of the common good but rather to more sectional or private concerns").

271. See, e.g., The Federalist No. 1 (Hamilton) ("[O]f those men who have overturned the liberty of republics, the greatest number have begun their career by paying an obsequious court to the people, commencing demagogues and ending tyrants."); STAN VAN HoOfT, Hope (THE ART OF LiVING) 96 (2014) ("Promising to save their people from oppression and exploitation, to bring an end to their humiliation and defeats, to restore the dignity and power of their race . . . has always been the modus operandi of fascist demagogues and populist rabble-rousers." ).

272. See James W. Ceaser, Presidential Selection: Theory and Development 61 (1979) ("The possibility of a national demagogue was one of the greatest fears of the Founders and literally frames The Federalist, being mentioned in both the first and last numbers.").

273. Zephyr Teachout, The Anti-Corruption Principle, 94 Cornell L. Rev. 341, 352 (2009) ("The Constitution was intended to provide structural encouragements to keep the logic and language of society as a whole from becoming corrupt, representing a technical and moral response to what they saw as a technical and moral problem."). 
exacerbating political polarization for short-term political gain, elite arrogance, institutional failure, and loss of public faith have spewed forth a demagogue whose populist appeals, brash personality and dishonest tactics almost perfectly fit the classical description. Not only has the demagogue taken over one of the two major political parties, he has actually won the presidency.

The framers knew that corruption comes to republics both from within and from without. They understood that foreign powers would be happy to sow confusion and disorder within a republic to benefit their interests. ${ }^{274}$ This fear has also been realized in 2016. Amazing as it seems, there is evidence that the Russian government engaged in a systematic disinformation campaign to confuse and mislead the American electorate, and to help to throw the election to Donald Trump, widely thought to be more pro-Russian than Hillary Clinton. ${ }^{275}$

In short, democratic dysfunction, and what the founders would have called republican corruption, has brought forth a demagogue. According to the familiar story, the next step is that the demagogue becomes a tyrant, and the tyrant ends republican government.

Is that how the story continues?

\section{REPUBLICAN FAILSAFES AND REPUBLICAN INSURANCE}

You fear the worst, Sandy, and raise the specter of secession and civil war.

274. $C f$. The Federalist No. 68 (Hamilton) (“"E]very practicable obstacle should be opposed to cabal, intrigue, and corruption. These most deadly adversaries of republican government might naturally have been expected to make their approaches from more than one quarter, but chiefly from the desire in foreign powers to gain an improper ascendant in our councils."). In his Farewell Address, George Washington connected the dangers of faction with the dangers of foreign influence that might capitalize on it: factionalism "opens the door to foreign influence and corruption, which find a facilitated access to the government itself through the channels of party passions. Thus the policy and the will of one country are subjected to the policy and will of another." George Washington, Farewell Address (1796), AvAlON PrOJECT, http://avalon.law.yale.edu/18th_ century/washing.asp [https://perma.cc/3HUR-T65A].

275. Adam Entous et al., Secret CIA Assessment Says Russia Was Trying to Help Trump Win White House, WASH. Post (Dec. 9, 2016), https://www.washingtonpost.com/world/nationalsecurity/obama-orders-review-of-russian-hacking-during-presidential-campaign/2016/ 12/09/31d6b300-be2a-11e6-94ac-3d324840106c_story.html?utm_term=.fd46ca7d3b23 [https://perma.cc/4MNC-UEWK] ("The CIA has concluded in a secret assessment that Russia intervened in the 2016 election to help Donald Trump win the presidency, rather than just to undermine confidence in the U.S. electoral system."); Craig Timberg, Russian PropagandaEeffort Helped Spread 'Fake News' During Election, Experts Say, Wash. Post (Nov. 24, 2016) https://www.washingtonpost.com/business/economy/russian-propaganda-effort-helped-spread-fakenews-during-election-experts-say/2016/11/24/793903b6-8a40-4ca9-b 712 716af66098fe_story.html?utm_term=.81bb60ab8cca [https://perma.cc/H73P-45D7] ("[A] sophisticated Russian propaganda campaign ... created and spread misleading articles online with the goal of punishing Democrat Hillary Clinton, helping Republican Donald Trump and undermining faith in American democracy.”). 
I do not argue that the prospects for American democracy are particularly bright in the near term. But the familiar story of the decline and fall of republics is not destined to be our fate, at least not yet.

Remember that the American Constitution - the very constitution that you have so eloquently criticized - is not simply a set of procedures for selfgovernance. Our Constitution was also designed to be a device for resisting demagogues. It trades off the best possible system of democratic governance in order to avoid the worst.

A constitution is designed to make politics possible. ${ }^{276}$ It is designed to make people engage in politics rather than have the struggle for power degenerate into anarchy, dictatorship, or violence. A well-designed republican constitution, accordingly, is designed to make republics possible, and to keep them operating as republics over time, despite the multiple temptations and corruptions that republics historically suffer. Such a constitution may be awkward in many respects. But that is acceptable if the awkwardness buys insurance against republican corruption-because that corruption, unchecked, leads to tyranny, anarchy, and civil war.

This point about constitutional structures as insurance against demagogues is the converse of an argument you have often made about the undemocratic defects of our constitutional system. You point out that there are several features of the Constitution that may not cause serious problems in the ordinary course of affairs. Yet, as you have often reminded me, building a house on a hundred-year flood plain involves the risk that, every hundred years or so, there will be a flood that will destroy your property. In the same way, you point out that, every now and then, undemocratic features of the Constitution may seriously frustrate democratic will. ${ }^{277}$ This risk motivates your argument for reforming our constitutional system to get rid of its inefficient and undemocratic features.

But the flip side of this argument is that certain features of a constitution may not merely be kludges or inefficient compromises that undermine democracy. Rather, they may trade off democratic efficiency in the ordinary course of affairs for political failsafes. Such political failsafes keep the struggle for power within republican politics rather than spinning out of control into tyranny and civil war.

These features of our constitutional system are often described as slowing down politics and making change more difficult. But many of these features do more than simply block precipitous action; they also give many different people and groups a stake in governance so that they have reason to continue to work within the political constitution rather than outside it. These failsafes are a kind of republican insurance. They act as checks on situations that may only rarely come to pass, but they serve as security for moments when, to borrow your metaphor, great political floods threaten to overwhelm the entire republic.

276. Balkin, supra note 150 , at 243.

277. Cf. Sanford Levinson, What Are We To Do About Dysfunction? Reflections on Structural Constitutional Change and the Irrelevance of Clever Lawyering, 94 B.U. L. REv. 1127, 1132 (2014) (comparing Constitution to a car with defective brakes, and arguing that "the Constitution is long overdue for a "trip to the shop"'). 
You might think of a well-designed constitution like a well-designed cybersecurity system. A computer system connected to the Internet is constantly being bombarded by various kinds of cyber attacks. Viruses and worms are always trying to infect it. Social engineers - that is, con artists and tricksters - are always trying to hack the system through ruses and tricks. (Apparently this is how the DNC and John Podesta's e-mails were hacked). ${ }^{278}$ A good security system - there is no perfect system - tries to ward off these constant attacks as best it can, and it inevitably trades off other goods in order to achieve a decent modicum of security.

Like most well-designed security systems, a good system for defending republican government does not have a single door with a single lock to be picked. Rather it has multiple layers and perimeters of defense. ${ }^{279}$ Some of these defenses are hard-wired into the constitutional text, while others, although not hard-wired, are part of the constitution of settlement. Many, if not most of them, make the system more undemocratic in your terms. Yet, to continue to metaphor of computer security, what you have described as bugs in the American constitutional system can also be understood as a features.

Some of the defenses in our constitutional system prevent demagogues from ever achieving political prominence. Others prevent them from being placed on the ballot as candidates in a general election. Others keep them from being elected. And still others limit what demagogues can do once they achieve office.

Several of these constitutional defenses, designed to prevent demagogues from ever gaining power, have already fallen in the course of the 2016 election. But others do not kick in until the demagogue becomes President. The question we now face is whether these remaining defenses will hold. There is still hope. And if we get to the 2020 and 2024 elections intact, with checks and balances, with functioning courts, with a smooth rotation of political power, in which the losers leave office peacefully and the winners don't exact revenge on them, our system will have proved robust as a constitution against demagogues. Don't get me wrong: a great deal may have been lost or damaged in the process, but the republic will have survived. In situations like the present, one has to scale back one's ambitions, and defend the core of the constitutional project.

One of the ironies of our exchange as it has developed over the course of a year is that you find yourself arguing for the use of these failsafes, these defenses

278. Ben Gilbert, Hillary Clinton's Campaign Got Hacked by Falling for the Oldest Trick in the Book, BuS. INSIDER (Oct. 31, 2016), http://www.businessinsider.com/hillary-clinton-campaignjohn-podesta-got-hacked-by-phishing-2016-10 [https://perma.cc/6ENP-XAZF] ("Phishing is a hacking tactic that is actually older than computer-based hacking, and it involves simple social engineering.").

279. See, e.g., James S. Tiller, The Ethical Hack: A Framework for Business Value PENETRATION TESTING 45-46 (2004) (describing defense-in-depth approaches with multiple layers of security); Nimmy Reichenberg, Four Tips for Designing a Secure Network Perimeter, SECURITY WEEK (Sept. 26, 2013), http://www.securityweek.com/four-tips-designing-secure-networkperimeter [https://perma.cc/ZA7D-F9HE] ("A sound network security perimeter architecture requires multiple layers of defense.”). 
of republican government. Neither of us likes the Electoral College, and you have identified it as a key example of what is undemocratic about our Constitution. In 2006, for example, you wrote that "the Electoral College ... supplies the decisive and overriding reason for rejecting the status quo and supporting a convention entitled to propose significant revisions. It is an undemocratic and perverse part of the American system of government that ill serves the United States."280 Nevertheless, in today's desperate circumstances, you argue that public-spirited individuals and groups should push for members of the Electoral College to support someone other than Donald Trump on December 19th. Consistent with the republican tradition of devotion to the common good, you argue that liberals and Democrats should put aside their short-term self-interest and get behind a consensus candidate from the Republican party, because that is the best way to ensure that the nation will accept the legitimacy of the result.

Denying Trump an Electoral College majority, in turn, would throw the presidential election into the House of Representatives, in which each state delegation would have one vote. ${ }^{281}$ California and Wyoming would have an equal say in who becomes our next president-a system of voting every bit as undemocratic as the malapportioned Senate. Your hope is that the House would pick an alternative to Trump-even someone who had never faced the voters in 2016. In 2006, you stated your staunch opposition to this particular feature of our Constitution; indeed, you called it "a national constitutional crisis just waiting to happen." 282

In ordinary times - indeed, as recently as a year ago-you would have pointed to the Electoral College and the House's power to choose the President as some of the worst features of our Constitution because they are so deeply in conflict with democratic norms. But, as you have pointed out, these are not ordinary times. And the argument in your last letter makes the case for the importance of republican failsafes in a democratic constitution.

Even so, I am skeptical about your particular solution. The Electoral College and the House of Representatives might have helped to preserve republican government in the early $1800 \mathrm{~s}$. After all, in the election of 1800 they eventually gave us Thomas Jefferson rather than Aaron Burr. But it is less likely that they will have the same effect in 2016. Neither the Electoral College nor the House of Representatives offers a very significant chance of preventing Trump's election. The solution you propose requires a great deal of coordination among strangers, and it requires that the Republican Party quickly converge on a consensus candidate in opposition to Trump, something the party was conspicuously unable to do throughout the Republican primary process.

Beyond the Electoral College, however, lie many other failsafes in our constitutional system. Most of them form part of what you call the constitution of settlement; some of them are hard-wired into the Constitution and would require an Article $\mathrm{V}$ amendment to change. You would probably regard almost

280. LEVINSON, supra note 54, at 82.

281. U.S. CONST. amend. XII.

282. LeVINSON, supra note 54, at 91. 
all of them as either undemocratic or as unduly limiting the ability of We the People to act expeditiously to realize their will.

\section{REPUBLICAN DEFENSE}

What are these remaining defenses? They include the staggered system of elections for President, Senate and House; the requirements of bicameralism and presentment; the internal rules of the Senate and House, ${ }^{283}$ the filibuster, and the various limitations on the use of the reconciliation procedure to get around the filibuster. ${ }^{284}$

Other defenses arise from our federal system: separate state governments with multiple offices that answer to different constituencies than the federal government, and the practical necessity of power sharing between federal and state governments in a host of federal programs. ${ }^{285}$ These practical features of federalism are far more important to the preservation of republican government than the entire history of judicial attempts at protecting state sovereignty or imposing dual federalism. They protect republicanism by continuously generating a cadre of opponents to contest the dominant regime, and by giving these opponents a stake in engaging in politics within the system rather than outside of it. As long as the opposition party can exert influence in state and local government, it is never fully shut out of politics. ${ }^{286}$ It can live to fight another day. Indeed, the party system often operates counter-cyclically: as one party dominates the presidency, the other often makes gains in Congress, and especially in state and local governments. ${ }^{287}$

When Trump takes office in January 2017, Republicans will control both

283. Balkin, supra note 16, at 1166.

284. For a valuable discussion, see David Super's three-part series on Balkinization. David Super, Inside the Strange World of "Reconciliation," BALKINIZATION (Dec. 4, 2016), https://balkin.blogspot.com/2016/12/inside-strange-world-of-reconciliation.html [https://perma.cc/MLY9-67WZ]; David Super, How Reconciliation Works: What it Can and Cannot Do, BALKInIZATION (Dec. 5, 2016), https://balkin.blogspot.com/2016/12/howreconciliation-works-what-it-can.html [https://perma.cc/J59L-CSMK]; David Super, What the New Majority Will Do-And How They Will Do It, BALKINIZATION (Dec. 6, 2016), https://balkin. blogspot.com/2016/12/what-new-majority-will-do-and-how-they.html [https://perma.cc/5KT5W3Y6].

285. See, e.g., Abbe R. Gluck, Intrastatutory Federalism and Statutory Interpretation: State Implementation of Federal Law in Health Reform and Beyond, 121 YALE L.J. 534 (2011); Jessica Bulman-Pozen \& Heather K. Gerken, Uncooperative Federalism, 118 YALE L.J. 1256 (2009); Heather K. Gerken, Of Sovereigns and Servants, 115 YALE L.J. 2633 (2006).

286. Heather K. Gerken, Dissenting by Deciding, 57 StAN. L. Rev. 1745 (2005).

287. Larry J. Sabato, Why Parties Should Hope They Lose the White House, Politico (Dec. 1,2014), http:/www.politico.com/magazine/story/2014/12/presidents-bad-for-their-parties-113241 \#ixzz3Pqkfx2ja [https://perma.cc/5F7M-ZBAJ] (arguing that "the surest price the . . party [winning the White House] will pay is defeat of hundreds of their most promising candidates and officeholders for Senate, House, governorships, and state legislative posts"). 
Houses of Congress and most state legislatures. But a regular system of staggered elections - every two years for the House, every four for the President, and every six for the Senate-is hard-wired into the Constitution. This distinguishes our presidential system from the sort of parliamentary systems you favor. It guarantees that it is very difficult for one party to hold on to all of the levers of power for an extended period of time. It makes revolutionary change difficult, unless the people keep returning the same party to power over and over again.

The staggered system of elections is the Constitution's most overlooked weapon against the rise of dictatorship. Generally speaking, the President's party usually loses seats in Congress during the mid-term elections. If President Trump proves incompetent or unpopular, he may well lose control of one or both houses of Congress by 2018. Even if that doesn't happen-because of gerrymandered House districts and the large number of Senate seats Democrats must defend in 2018 - the Democrats might still gain enough seats to make it difficult for Republicans to pass legislation through Republican votes alone. At that point, many of Trump's most dangerous plans will be off the table.

The 2018 and 2020 elections are especially important because they will determine who draws the redistricting maps for both state and federal elections in the next decade. Republicans leveraged their successes in the 2010 election to lock in a partisan advantage both in state legislatures and in the House of Representatives. Democrats have a chance to undo some of those advantages in the next decade.

These structural defenses can't prevent everything, of course. As you and I have written in our work on constitutional dictatorship, over the years Congress has delegated so much control to the White House that in many aspects of domestic and foreign policy the President can act unilaterally. ${ }^{288}$ The sad fact is that Trump doesn't need to innovate all that much to cause a great deal of damage to our national interests - he can rely on the techniques that previous presidents have developed. Many of these techniques were developed by presidents who faced increasing gridlock, government inertia, and congressional irresponsibility. But tools crafted with best of intentions can still be abused by later presidents. We can only guess what Trump will do with the quasi-dictatorial powers of the modern presidency. (At the same time, executive overreach will open up another potential site of resistance-through judicial review of the administrative state.)

And then there is the elephant in the room: the possibility of another terrorist attack on American soil. Unlike George W. Bush, Trump might be blamed for it, further diminishing his ability to govern effectively. But it is also possible that he will use the attack as an opportunity to expand the powers of the President and limit civil liberties. He will rally his supporters, find his scapegoats, and demand the power to act quickly and effectively. He will confuse energy and initiative with cruelty and self-aggrandizement, as demagogues so often do.

288. See Balkin \& Levinson, supra note 252, at 1813-14 ("the expansion of presidential authority ... has come through the creation of framework statutes by Congress that ... delegate vast authority to the President."). 


\section{How to Defeat a Demagogue}

There are no guarantees, but the system of staggered elections is among the most important defenses the American Constitution presents to demagogic ambitions. In a parliamentary system, one might hope to generate a vote of noconfidence and cause the leader's government to fall. But in the American system, the most important thing one can do to counter a demagogue is to win successive elections at both the state and federal level.

Complaining that Trump is arrogant, ignorant, uncouth, and corrupt is not the most likely means of winning those elections. Trump's supporters already know that he is arrogant, ignorant, uncouth and corrupt, but they voted for him anyway. They supported him because they wanted dramatic change that would make their lives better. Some of the people who voted for him didn't like him at all, but merely regarded him as the lesser of two evils; they hoped against their better judgment that he could change things for the better.

Understanding all this is the key to the proper political strategy. The way to defeat Trump is not to reveal him as a vulgarian, or even as corrupt or selfdealing, but to fight him on grounds of policy. His power is his promise of change. Explode the promise and his magic dissipates.

It is not enough to show that Trump is a hypocrite-one must show that he is an ineffective hypocrite. Demonstrate that his promises of change were illusory, and that his policies hurt the very people who supported him. Make people want to give the other party a chance, just as they have done so many times before. This was the sword that Trump wielded against Hillary Clinton; and it is the weapon that might be wielded against Trump. Trump enters the White House without a popular majority, and with some of the lowest net favorability ratings of any first-term President in recent American history. ${ }^{289}$ A majority of the public is already skeptical of him, and may turn on him if he cannot quickly bring significant reform to an increasingly restless America.

The credibility of a demagogue like Trump stems from his promise to shake up the lethargy of government, to bring change, and to improve people's lives. The source of his power is also the source of his greatest vulnerability. To defeat him, one must bog him down, divert him, frustrate him, waste his energies.

I have argued that Trump appears at the end of the Reagan regime; he enters the White House when his party's coalition is weak and factionalized. ${ }^{290}$

289. Jonathan Easley, Trump's Popularity Spikes, but Lags Behind Past Presidents, THE HILL (Dec. 8, 2016), http://thehill.com/homenews/campaign/309319-trumps-popularity-spikes-but-lagsbehind-past-presidents [https://perma.cc/3APN-633N] ("Trump's net favorability rating is the lowest of any newly elected first-term president, likely because he was a controversial candidate who caused divisions in his own party."); Views of President-Elect Trump and His Administration, PEw Res. CTR. (Dec. 8, 2016), http://www.people-press.org/2016/12/08/1-views-of-president-electtrump-and-his-administration/ [https://perma.cc/42CQ-HDJT] (“Trump's rating for the job he has done so far presenting his vision to the public is lower than those other recent presidents received following their elections.").

290. Jack M. Balkin, What Kind of President Will Donald Trump Become, Part II-Donald 
Therefore, I believe that he is primed for what Stephen Skowronek calls the politics of disjunction, in which a President allied with an aging political regime promises to restore its dominance and former greatness, is unable to keep all of the factions of his party together, and as a result presides over the regime's dissolution. ${ }^{291}$ Disjunctive presidencies are usually failures; the opposition party successfully repudiates them, producing a new and robust political regime to replace them. ${ }^{292}$

There are good reasons to believe that Trump will face a disjunctive situation, bringing the Reagan era to a close.$^{293} \mathrm{He}$ fits many features of the ideal type. For example, although nominally affiliated with a decaying regime, "the actions these presidents take on their own behalf are as disruptive to the status quo as any." 294 Indeed, Skowronek notes, "one of the great ironies of the politics of disjunction is that the presidents who come to office in these sorts of situations tend to have only the most tenuous relationship to the establishments they represent." "Long-festering problems within the regime" 296 tend to produce leaders "only nominally affiliated with it." ${ }^{297}$ In trying to fix the country's problems, they "often press major departures of their own from the standard formulas and priorities set in the old agenda." 298

As differences within the coalition become increasingly obvious and difficult to manage, disjunctive candidates argue that they are able to fix things because they have special technical abilities. ${ }^{299}$ For example, they might portray themselves as extremely skilled diplomats and politicians (John Quincy Adams, James Buchanan), outstanding technocrats and problem solvers (Herbert Hoover, Jimmy Carter); or, as in Trump's case, outstanding deal makers. They explain to the public that what is important is not ideological purity but the ability to get things done.

In like fashion, Trump has used his image as a successful businessman who is good at making deals to assuage different parts of the Republican coalition. As Skowronek puts it, in the last days of a regime, mastery of technique - in this case deal making and business acumen- "is a hallmark of the politics of disjunction. ${ }^{300}$ Focusing on technique allows the new President to remain ambiguous about what he or she stands for. This allows each side of the coalition

Trump and the Politics of Disjunction, BALKINIZATION (Nov. 14, 2016), https://balkin.blogspot. com/2016/11/what-kind-of-president-will-trump.html [https://perma.cc/8U52-WP59].

291. See Stephen Skowronek, The Politics Presidents Make: Leadership from John Adams to Bill Clinton 39-40 (3d prtg. 2000).

292. Id. at 39-41.

293. Balkin, supra note 290.

294. SKOWRONEK, supra note 291 , at 40.

295. Id.

296. Id.

297. Id.

298. Id.

299. The next three paragraphs are adapted from Balkin, supra note 290.

300. SKOWRONEK, supra note 291, at 40. 
to believe that it will get what it wants from the new presidency.

Unfortunately, the politics of disjunction presents a gauntlet that is close to impossible to traverse successfully. Disjunctive presidents are caught between the demands of increasingly antagonistic factions, whom they cannot all please simultaneously. Technique is not enough to keep the coalition together or maintain its legitimacy. Being a great deal maker, for example, is not enough if people don't like the deals, or if they come to believe that you have sold them out. Eventually such presidents discover they cannot maintain public support; they are undone by internal divisions within their own party, resistance from the opposition party, and the unexpected calamities that befall every presidency.

There are no guarantees that Trump will fit into a predetermined ideal type. He has confounded expectations many times before. Nevertheless, our best hope is to act on these assumptions about where we stand in political time. History will not take care of itself; these kinds of leaders fail because people actively oppose them. They fail because their political coalition begins weakened and falls apart in the face of constant political opposition. If Trump's political coalition is fractious, one must prevent it from coalescing and regaining strength. One must work continuously to split his coalition, by highlighting the choices that divide congressional Republicans, by finding common ground with NeverTrumpers, and by peeling off people who only viewed Trump as the lesser of two evils.

Above all, to defeat a demagogue whose power comes from the promise of change, one must make change difficult, and impede the smooth progress of his Administration's ambitions. In constitutional terms, one must use all of the tools in the American constitutional system to hinder, delay, and frustrate his efforts. To defeat a demagogue like Trump, in other words, one must use the tools that you, Sandy, have repeatedly denounced as making our Constitution undemocratic. In a period of abnormal politics, our goal is not a frictionless path for official action; instead, we must defend the republic.

This brings our discussion full circle, back to the issues that began our debate. Without defending all of the undemocratic features of our constitutional system, let me suggest that at least some of them serve as crucial insurance for republicanism. The next few years will demonstrate their value, and your proposals to eliminate or displace them are badly timed.

For example, you have previously supported the idea of national referenda to circumvent a stagnant political process. But nothing could be more dangerous when a demagogue holds the reins of power. There is nothing a demagogue likes more than to circumvent established forms of lawmaking to project his power and identify his will with the will of the people.

You have also argued for a constitutional convention to propose new amendments. But calling for a constitutional convention just as a demagogue has won the presidency is the worst possible example of political timing. Trump won the 2016 election because he fired up a populist political movement that endorses his call to blow up the system. His followers will surely be major participants in any new constitutional convention. At best the convention would be futile, because the country is now too deeply divided to achieve ratification by three quarters of the states. At worst it would be dangerous, because Trump's ability to influence both the convention and Republican-controlled state legislatures 
might result in authoritarian changes to our constitutional system. Even if you are correct that we need new constitutional amendments, the moment for an Article $\mathrm{V}$ convention can't arise until the demagogue is thoroughly defeated and discredited.

\section{Conclusion: A Machine That Would Not Go of Itself}

There is a famous conceit that the framers sought to create a republican machine that would go of itself, a Newtonian contraption that would check and balance powers so effectively that the republic's continuation would be assured. ${ }^{301}$ All later generations have to do is stick to the framers' design and all will be well.

This was always a pipe dream. The framers did not think themselves so omniscient. They knew the history of republics, their frailty and fragility; and they knew their own shortcomings as fallible human beings. Above all, they understood that in the long run no republic can survive without political faith, without the dedication of each generation of its citizens to the public good, and without the continual maintenance of institutions of civil society-including media and educational systems - that support and nourish self-governance.

Over two centuries later, we likewise understand that the machine will not go of itself. It has taken - and will take-the efforts of many people to oppose recurring threats to our democracy and to restore trust in our institutions when our political faith is challenged. What constitutional structure can do is make these tasks easier or harder to achieve. That is why the study of constitutional structure, and what you have called the constitution of settlement, is so important.

The American Constitution failed once before, in 1860. It might fail again. But over the years, from the founding to the present, Americans have built their Constitution with the possibility of failure in mind. They have sought to accommodate and incorporate change while limiting the number of constitutional failures-or, at the very least minimizing the effects of constitutional failure so that Americans can rebound from it. The framers knew that no constitution is perfect, and that no republic lasts forever. Whether our Constitution works well or badly can only be tested through time and experience. We have come upon such a test right now.

Your devoted friend,

Jack

301. See Michael Kammen, A Machine that Would Go of Itself: The Constitution in AMERICAN Culture 18-19 (1986) (quoting James Russell Lowell's 1888 speech to the Reform Club of New York). Lowell, it should be noted, warned against the "complacency" of the metaphor. 